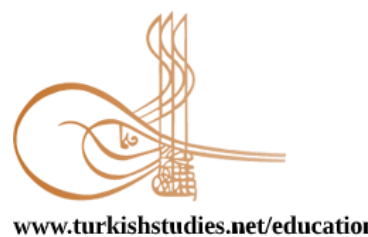

www.turkishstudies.net/education
Turkish Studies - Educational Sciences

eISSN: 2667-5609

Research Article / Araștırma Makalesi

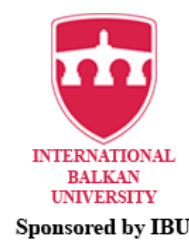

Sponsored by IBU

\title{
İlköğretim Matematik Öğretmen Adaylarının Matematiksel Akıl Yürütme ve Problem Çözme Becerilerine İlişkin Görüşleri*
}

\author{
Views of Pre-Service Mathematics Teachers Regarding Mathematical Reasoning and Problem- \\ Solving Skills
}

\author{
Halil Coşkun Çelik ${ }^{* *}$ - Mustafa Obay ${ }^{* * *}$ - Furkan Özdemir ${ }^{* * * *}$
}

\begin{abstract}
The aim of this study is to examine the views of pre-service mathematics teacher on mathematical reasoning and problem-solving skills. The study will contribute to the determination of how, where, when and for what purpose pre-service mathematics teachers can use their mathematical reasoning skills in teaching activities and the reasons why learners can make these associations during the problem solving process. The data on which the study is based are thought to contain important signs of how pre-service mathematics teachers can gain mathematical reasoning and problem solving processes to students and how to use them successfully. The study was designed in phenomenological model of qualitative research methods. The study was carried out on 107 pre-service teachers who were studying in the department of primary mathematics education and selected for purposive sampling method. In order to collect data, the Semi-Structured Interview Form which was developed by the researchers was used to determine the pre-service teachers' views on mathematical reasoning and problem solving. The data obtained through this form were analyzed by the content analysis method. When the research results are examined; It is determined that pre-service teachers do not have enough knowledge about reasoning, they need such education and they have positive attitudes towards reasoning. On the other hand, pre-service teachers stated the problem as a pending action and problem. In addition, it is thought that deeper investigation is still needed on the phenomenon of reasoning in terms of learner groups.
\end{abstract}

\footnotetext{
* Çalışma 2018-2019 eğitim-öğretim yılında yürütülmüştür. This study was conducted in 2018-2019 education year.

** Doç. Dr., Siirt Üniversitesi, Eğitim Fakültesi, Matematik ve Fen Bilimleri Eğitimi Bölümü. Assoc. Prof. Dr., Siirt University, Faculty of Education, Department of Mathematics and Science Education. ORCID 0000-0003-0056-5338

hcoskun.celik@gmail.com

**** Dr. Öğr. Üyesi, Siirt Üniversitesi, Eğitim Fakültesi, Matematik ve Fen Bilimleri Eğitimi Bölümü.

Assist. Prof. Dr., Siirt University, Faculty of Education, Department of Mathematics and Science Education. ORCID 0000-0002-2537-9438

mustafaobay@gmail.com

***** Dr., Siirt Üniversitesi, Eğitim Fakültesi, Matematik ve Fen Bilimleri Eğitimi Bölümü.

PhD, Siirt University, Faculty of Education, Department of Mathematics and Science Education.

ORCID 0000-0001-9116-1480

furkanozdemir24@gmail.com

Cite as/ Atıf: Çelik, H. C., Obay, M. \& Özdemir, F. (2020). İlköğretim matematik öğretmen adaylarının matematiksel akıl yürütme ve problem çözme becerilerine ilişkin görüşleri. Turkish Studies - Education, 15(3), 1651-1673. https://dx.doi.org/10.29228/TurkishStudies.42682

Received/Geliş: 28 March/Mart 2020

Accepted/Kabul: 22 June/Haziran 2020

Copyright (C) INTAC LTD, Turkey

Checked by plagiarism software Published/Yayın: 25 June/Haziran 2020 CC BY-NC 4.0
} 


\section{Structured Abstract: Introduction}

Reasoning; considering all factors, it is a process of reaching a rational conclusion (Umay \& Kaf, 2005). Reasoning is an important process that needs attention in mathematics teaching, especially without excluding other skills in higher education (Rohana, 2015). The aim of mathematics taught in the mathematics departments of universities is to provide students with in-depth knowledge of mathematics, to develop mathematical thinking skills and to enable them to gain awareness about the related fields and applications of mathematics. The way to fully learn mathematics and to be successful in mathematics goes without mathematical reasoning and thinking (Öz \& Işı, 2018). The teacher should be able to mobilize the mathematical reasoning of the student and give them the opportunity to create new mathematical ideas and solutions (Baki, 2018). This is the problem solving, reasoning, mathematics and daily life, school experience and teaching practice. require the ability to apply the knowledge gained from the courses to the classroom environment. Therefore, systematic evaluation of the pre-service teachers' opinions on reasoning will contribute to the determination and elimination of the shortcomings of the prospective teachers while on the other hand they will enable their students to develop their reasoning and mathematical thinking skills in mathematics courses. Our current study will contribute to the determination of the reasons why mathematicians can use mathematical reasoning skills in teaching activities, where, when and for what purpose, and whether they can make these associations in the problem-solving process.

The aim of this study is to examine the views of mathematics teacher candidates on mathematical reasoning and problem-solving skills. The data on which the study is based are thought to include important signs of how to use mathematical reasoning and problem-solving processes to teach students and how to use them successfully.

\section{Method}

In this study, phenomenological study pattern of qualitative research methods is used. The phenomenology pattern focuses on the facts that we are aware of but do not have a deep and detailed understanding. The study was carried out with 107 pre-service mathematics teachers from 2 nd, 3rd and 4th grades of primary education in a public university in Southeastern Anatolia Region in the 2018-2019 academic year fall semester. During the selection of the participants, the students took lessons-based learning and problem-solving strategies in which the logic of reasoning and problem-solving skills were taught, and a certain level of mathematics experience was taken into consideration. In this research, a semi-structured student interview form, which was developed by the researchers as a data collection tool, was used to investigate the views of mathematics teachers about problem solving and mathematical reasoning. Content analysis used.

\section{Findings}

To determine the problem perception of teacher candidates What do you think is the problem? How do you define? in the form of an opinion question. Considering the answers to this question and the findings obtained from the research together, the problem for the pre-service teachers can be evaluated as a problem. Again, the participants' opinions on the definition of the problem are close to the meanings mentioned above as difficulty, difficulty category. In addition, it can be said that teacher candidates mostly understand the problem without solving the mathematical problem. On the other hand, it can be said that prospective teachers do not have sufficient knowledge about reasoning. In another finding, it was observed that the teacher candidates stated that they did not have a sufficient level of reasoning education. As we can evaluate this in the absolute sense, we can also consider that the pre-service teachers are not aware of their reasoning skills which are taught without being called informal. For the relationship between problem solving and reasoning, teacher candidates have the opinion that it does not seem possible to solve problems without reasoning. The pre-service teachers mostly expressed the chess game as the reasoning game. Another important finding is that there is a strong positive correlation between mathematical reasoning and mathematics achievement according to the opinions of teacher candidates. In other words, mathematical reasoning skill increases math achievement. A stunning finding in the study can be said that pre-service teachers do not know and define the reasoning concept well. When the opinions of the pre-service teachers on the development of reasoning skills are examined, it can be said that the play activities have an important place. 


\section{Discussion, Conclusions and Recommendations}

According to the study results, it can be said that pre-service teachers do not have sufficient knowledge about reasoning, they need such education, they have intuitive knowledge about some of their components and have a positive attitude towards reasoning. On the other hand, despite all the education received, it can be said that the pre-service attitude of the pre-service teachers and their attitudes towards the problem solving continued and they kept their results-oriented thinking processes in this direction. Furthermore, as far as this study shows, there is still a need for deeper investigation on the phenomenon of reasoning in terms of learner groups. It is clear that pre-service teachers have insufficient comments about what the problem is. In this respect, constructing the relations between problem-solving and reasoning in the right perspective will have a positive effect on how teacher candidates should reason in different situations. In order to realize this aim, a number of developments on the basis of both the curriculum and the course contents of the proposal of the researchers suggest that the pre-service teachers and thus the student population that will be trained will contribute to the understanding and success of the mathematics.

Keywords: Mathematics education, mathematical reasoning, mathematics achievement, pre-service teachers, problem solving.

Öz: Bu çalışmanın amacı ilköğretim matematik öğretmen adaylarının matematiksel akıl yürütme ve problem çözme becerisine ilişkin görüşlerini incelemektir. Çalışma matematik alanında, özellikle matematik öğretmen adaylarının öğretim faaliyetlerinde matematiksel akıl yürütme becerilerini nasıl, nerede, ne zaman ve hangi amaçla kullanabilecekleri ve öğrenenlerin problem çözme sürecinde bu ilişkilendirmeleri yapıp yapamamalarının nedenlerinin tespiti konusunda katkıda bulunacaktır. Çalışmanın dayandığı verilerin, matematik öğretmen adaylarının matematiksel akıl yürütme ve problem çözme süreçlerinin öğrencilere nasıl kazandırılacağı ve başarılı bir şekilde nasıl kullanılacağına dair önemli işaretler içerdiği düşünülmektedir. Çalışma nitel araştırma yöntemlerinden fenomenolojik desende tasarlanmıştır. Araştırma Güneydoğu Anadolu bölgesinde bulunan bir üniversitenin eğitim fakültesi, matematik eğitimi anabilim dalında öğrenim gören ve amaçlı örnekleme yöntemiyle seçilen 107 öğretmen adayı üzerinde yürütülmüş̧ür. Çalışmada veri toplamak amacıyla araştırmacılar tarafından geliştirilmiş öğretmen adaylarının matematiksel akıl yürütme ve problem çözme becerileri konusundaki görüşlerini belirlemek için yarı yapılandırılmış görüşme formu kullanılmıştır. $\mathrm{Bu}$ form yoluyla elde edilen veriler içerik analizi yöntemi ile çözümlenmiştir. Araştırma sonuçları incelendiğinde; öğretmen adaylarının akıl yürütme konusunda yeterli bir bilgi birikimine sahip olmadıkları, böyle bir eğitime ihtiyaç duydukları, akıl yürütmeye karşı olumlu tutumlar sergiledikleri tespit edilmiştir. Diğer yandan öğretmen adayları problemi çözüm bekleyen eylem ve sorun olarak gördüklerini belirtmişlerdir. Ayrıca öğrenen gruplar açısından akıl yürütme olgusu üzerinde hala daha derin inceleme yapılmasına ihtiyaç duyulduğu düşünülmektedir.

Anahtar Kelimeler: Matematik eğitimi, matematiksel akıl yürütme, matematik başarısı, öğretmen adayları, problem çözme.

\section{Giriș}

Matematik, akı1 yürütme ile elde edilen bilgidir (Rohana, 2015) ve günlük yaşamda karşılaştığımız problemlerin çözümünde kullanılan akıl yürütme süreçlerinde önemli rol oynar. Matematikçiler açısından akıl yürütme bir fikir veya kavramı bir sonraki kavram veya fikirle ilişkilendirme ya da onunla biçimlendirmedir (Brodie, 2010). Matematiğin öğrenciye kazandırması gereken beceriler arasında, akıl yürütme, ilişkilendirme, modelleme, problem çözme ve iletişim gelmektedir. Bu beceriler matematiksel temel kavramların ve matematiksel bilgi edinme yollarının öğrenilmesiyle geliştirilebilir (Baki, 2018).

\section{Matematiksel Akıl Yürütme}

Akıl yürütme, "eldeki bilgilerden hareketle matematiğin kendine özgü araç (semboller, tanımlar, ilişkiler, vb.) ve düşünme tekniklerini (tümevarım, tümdengelim, karşılaştırma, genelleme, vb.) kullanarak yeni bilgiler elde etme sürecidir" (Milli Eğitim Bakanlığı [MEB], 2013: 5). Umay ve 
Kaf (2005) akıl yürütmeyi, bütün etmenleri dikkate alarak düşünüp akılcı bir sonuca ulaşma süreci olarak düşünmektedirler. Thom'a (2011) göre akıl yürütme, "matematikle uğraşırken düşüncelerimizi ve eylemlerimizi doğrulamanın yanı sıra, varsayımları üretmeyi, uygulamayı ve değerlendirmeyi" içerir. Ayrıca matematiği tam manasıyla öğrenme ve matematikte başarılı olmanın yolu matematiksel akıl yürütme ve düşünmeden geçmektedir (Öz \& Işık, 2017).

Matematikte gerçeklere deneyle, gözlemle değil, yalnızca akıl yürütmeyle ulaşılır (Umay \& Kaf, 2005). Matematiksel akıl yürütme kanıtlara veya belirtilen varsayımlara dayanarak sonuç çıkarma sürecidir (National Council of Teachers of Mathematics [NCTM], 2009) ve matematiksel iddiaların gerekçelendirilmesinde ya da kanıtlanmasında merkezi olarak işlev görür (Ball \& Bass, 2003). Matematiksel olarak akıl yürütme, mantıksal, sistematik düşünme kapasitesini içerir (Trends in International Mathematics and Science Study [TIMSS], 2003). Belirli matematiksel fikirleri ve prosedürleri salt gerçek veya rutin olarak bilmek, bu fikirleri farklı durumlarda esnek bir şekilde kullanmak için yetersizdir; matematiksel akıl yürütme, talep olduğunda, unutulan bilgiyi yeniden kurmak için esastır (Ball \& Bass, 2003).

Bilişsel bir beceri olan matematiksel akıl yürütme analiz, sentez, genelleme yapma, karar verme ve rutin olmayan problemleri çözme becerilerini içerir (TIMSS, 2003). Akıll yürütme becerisini geliştirebilme yeterliği, öğrencilerin matematiksel akıl yürütmenin önemini kavrama, buna ilişkin etkinlikler düzenleme, matematiksel model, kural ve ilişkileri kullandırma, tahminler, çıkarımlar ve genellemeler yapma, akıl yürütmeyi yaşamda ve diğer disiplinlere entegre ettirme şeklinde performans göstergelerine sahiptir (Berkant \& Kandırmaz, 2018).

Akıl yürütme yeteneği, zihinsel kapasitenin ölçülmesi için bir yöntem olarak görülmektedir. Matematiksel akıl yürütme bir probleme farklı çözümler bulma yolunda problem çözme sürecinin bir bileşenidir. Dolayısıyla zihinsel bir beceri gerektiren problem çözme ile akıl yürütme arasında bir ilişkiden söz edilebilir. Ayrıca herhangi bir konuda akıl yürütme becerisine sahip olan öğrencilerin problem çözmede zorlanmaması bu ilişkiye destekler. Matematiksel anlayışın her seviyesinde akıl yürütme olabilmektedir ve matematiksel akıl yürütme, problem çözümünde tüm zorluk seviyelerinde kullanılabilmektedir (Jäder, Sidenvall, \& Sumpter, 2017). Problemleri çözme ve cevaplara ulaşma, yani çözümlere mantıksal bir şekilde ulaşma ve genelleme yapma yeteneğini de içerir (Fathima \& Rao, 2008).

\section{Problem Çözme Becerisi}

Problem, öğrenenlerin karşılaştı̆̆ 1 , çözüm gerektiren ve çözüm yolunun doğrudan bilinmediği bir durumdur (Posamentier \& Krulik, 2016). Problem çözme ise istediğini elde etmek için ne yapılması gerektiğini bulmaktan ibaret olan bir beceridir ve okul matematiğinin temel amacıdır (Najdowski, 2017). Öğrencilere 21 yüzyıl için gerekli bilgi ve becerileri kazandırmak matematik eğitiminde problem çözmeye odaklanmakla gerçekleşir. Öğrencilere gerekli becerileri kazandırmak, matematik eğitiminde problem çözme ile mümkün olabileceğinden, problem çözme matematik öğretim programlarında önem kazanmakta ve odak noktası olmaktadır (Baki, 2018). İlkokuldan üniversiteye tüm eğitim düzeyindeki öğrencilerin ortak bir işi (Najdowski, 2017) olan problem çözme, öğrencilerin karar vermelerinin yanı sıra pek çok matematiksel kavramları ve becerileri uygulamalarını ve birleştirmelerini gerektiren önemli bir unsurdur (Tambychik \& Meerah 2010).

Bir matematiksel durumun problem olabilmesi için, çözüme ulaşma yolunun açık olmaması ve öğrencinin mevcut bilgileri ile akıl yürütme becerilerini kullanmasını gerektirmelidir (Çiltaş, 2011). Problem çözmede, akıl yürütme etkin bir rol oynar. Problem çözme hafıza, algı, akıl yürütme, kavramsallaştırma, dil gibi duygusal kontrol, motivasyon, kendine güven ve izleme gibi entelektüel yetenekleri harekete geçirir (Garcíaa ve diğ., 2019). Problem çözme, öğrencilerin gerçek yaşamın birçok alanında akıl yürütmelerine yardımcı olur. Bu çerçevede öğrencilere matematik derslerinde ve gerçek yaşamlarında problem çözme becerilerini kazandırmak temel beklenti olmalıdır. 
Matematiksel problem çözme, bireyin yeni bir durumun taleplerini karşılamak için önceki deneyimlerini, matematiksel bilgi, anlayış ve sezgiyi koordine etmesini gerektiren karmaşık bir süreçtir (Kaur, 1997). Bu süreçte bir öğretim faaliyeti olarak problem çözme becerisi ve yeteneğinin işe koşulması öğrencilerin matematik derslerinde daha başarılı olmasını sağlayabilir. Öğrencilerin okul matematiğinde başarılı olmaları ve problem çözme becerilerini geliştirmeleri için becerilerini kullanabildikleri problem çözme vakalarıyla karşılaşmaları gerekir (Sevim, 2015).

Problem çözme süreci boyunca, öğrenciler yeteneklerini çözümleme, beyin firtınası yapmak, nedenleri belirlemek, çatışmalarla yüzleşmek veya çözmek için olası stratejileri veya çözümleri değerlendirmek ve sonunda en etkili çözümü uygulamak için becerilerini kullanacaklardır (Osman ve diğ., 2018). Bu kapsamda matematiksel problem çözme matematiğin öğretilmesi ve öğrenilmesi açısından önemli bir kazanım noktası olarak düşünülmektedir.

Problem çözme önceki bilgilerimizi organize etmeyi gerektirdiği gibi aynı zamanda öğrenme süreçlerinin farkındalığını da gerektirir. Ancak bazı öğrenme türleri tam farkındalık altında gelişmez. Örneğin informal öğrenme böyle bir öğrenmedir. Problem çözme süreci bir takım informal öğrenme bileşenini de içerir. Bu öğrenme önemli ölçüde görünmezdir, öğrenilen şey teşhis edilemez veya yanlış öğrenilebilir. Bu yüzden bu öğrenme stratejisinde öğrenen bireylerin kendi öğrenmelerine karşı farkındalıkları zayıftır (Eraut, 2004).

Matematiksel akıl yürütmenin öğrenme üzerindeki etkisi çeşitli araştırmalar için odak noktası olmuş ve farklı perspektiflerde incelenmiştir. Matematik başarısıyla ilişkili olan bir değisşken matematiksel akıl yürütme becerisidir (Campbell, Adams \& Davis, 2007; Sprigler \& Alsup, 2003) ve matematiksel akıl yürütme becerisi, "problem çözme becerisini" pozitif yönde etkilemektedir (Yurt \& Sünbül, 2014). Yeşildere ve Türnüklü (2007), akıl yürütme ve matematiksel düşünme süreçlerini konu alan çalı̧̧malarında, öğrencilerin problem çözme, akı1 yürütme ve matematiksel ilişkilendirme konusunda eksiklerinin olduğunu tespit etmişlerdir. Bu tespite neden olan faktörleri, öğrencilerin verilenleri kullanarak değil öznel görüşleriyle akıl yürütmeleri, düşüncelerini kanıtlayarak ve açıklamalar yaparak ifade edememeleri ve ilişkilendirme yaparak problemleri çözememeleri şeklinde sinıflandırmıştır.

Öğretmen öğrencinin matematiksel akıl yürütmelerini harekete geçirebilmeli, yeni matematiksel düşünceler ve çözümler oluşturmalarına firsat verebilmelidir (Baki, 2018). Bu da öğretmen adaylarının üniversite eğitimleri sırasında aldıkları problem çözme, akıl yürütme, matematik ve günlük yaşam, okul deneyimi ve öğretmenlik uygulaması vb. derslerden edindikleri bilgileri sınıf ortamına uygulayabilme becerilerine sahip olmalarını gerektirir. Dolayısıyla öğretmen adaylarının akıl yürütme konusundaki görüşlerinin sistemli bir şekilde değerlendirilmesi bir taraftan öğretmen adaylarının eksikliklerinin belirlenmesi ve giderilmesine katkı sağlarken, öte yandan matematik derslerinde öğrencilerinin akıl yürütme ve matematiksel düşünme becerilerinin geliştirilmesini sağlayabilecektir. Mevcut çalışmamız, kapsamı sınırlı olmakla birlikte, matematik alanında, özellikle matematik öğretmen adaylarının öğretim faaliyetlerinde matematiksel akıl yürütme becerilerini nasıl, nerede, ne zaman ve hangi amaçla kullanabilecekleri ve öğrenenlerin problem çözme sürecinde bu ilişkilendirmeleri yapıp yapamamalarının nedenlerinin tespiti konusunda katkıda bulunacaktır. Çalışmanın dayandığı verilerin, matematik öğretmen adaylarının matematiksel akıl yürütme ve problem çözme süreçlerinin öğrencilere nasıl kazandırılacağı ve başarılı bir şekilde nasıl kullanılacağına dair önemli işaretler içerdiği düşünülmektedir. Bu kapsamda çalışmanın genel amacı matematik öğretmen adaylarının matematiksel akıl yürütme ve problem çözme becerileri konusundaki görüsslerini incelemektir. Bu genel amaç doğrultusunda aşağıdaki alt problemlere cevap aranmıştır.

1. Öğretmen adaylarının problem, matematiksel problem çözme ve akıl yürütme tanımlarına yükledikleri anlamlar nelerdir? 
2. Öğretmen adaylarının matematiksel problem çözme ile akıl yürütme arasındaki ilişkiye yönelik görüşleri nelerdir?

3. Öğretmen adaylarının akıl yürütme türleri ve oyunlar1, ak1l yürütme becerisinin MEB ortaokul programında yer alıp almaması hakkındaki görüşleri nelerdir?

4. Öğretmen adaylarının lisans eğitimleri boyunca almış oldukları akıl yürütme kavramına yönelik eğitimler nelerdir?

5. Öğretmen adaylarının matematiksel akıl yürütme becerisi ile matematik başarısı arasındaki ilişkiye ve geometride akıl yürütmenin önemine yönelik görüşleri nelerdir?

6. Ö ğretmen adaylarının akıl yürütme becerilerinin nasıl geliştirilebileceği hakkındaki önerileri nelerdir?

\section{Yöntem}

\section{Araştırma Modeli}

Çalışmada nitel araştırma yöntemlerinden olgubilim (fenomenolojik) deseni kullanılmıştır. Olgubilim deseni, farkında olduğumuz, ancak derin ve detaylı bir anlayışa sahip olmadığımız olgulara odaklanmaktadır (Yıldırım \& Şimşek, 2013). Olgubilim çalışmalarının amacı bireylerin bir olguya ilişkin yaşantılarını, algılarını ve yükledikleri anlamları ortaya çıkartmaktır (Kocabıyık, 2015). Bu çalışmada da öğretmen adaylarının matematiksel akıl yürütme ve problem çözme konusundaki düşüncelerinin daha iyi anlaşılmasına odaklanıldığından olgubilim deseni tercih edilmiştir. Olgubilim çalışmalarının temel amacı, bir olguyla ilgili kişisel deneyimleri, daha genel bir düzeye çekmektir (Creswell, 2007). Yapılan çalışma da bu amaç hedeflenerek gerçekleştirilmiştir.

\section{Araştırma Grubu}

Bu çalışma, 2018-2019 öğretim y1lı güz döneminde bir devlet üniversitesinin eğitim fakültesi, matematik eğitimi anabilim dalında okuyan, 2.(30 kişi), 3. (26 kişi) ve 4. sınıf (49 kişi) düzeylerinden toplam 107 gönüllü öğretmen adayı ile yürütülmüş̧ür. Katılımcılar gönüllülük esasına çalışmaya katılmışlardır. Katılımcılar seçilirken, probleme dayalı öğrenme ve problem çözme stratejileri derslerini almış ve belli düzeyde matematik tecrübesine sahip olmalarına dikkat edilmiştir. Bu bakımdan katılımcı seçiminde amaçlı örnekleme yöntemlerinden ölçüt örnekleme kullanılarak öğretmen adayları seçilmiştir. Fenomenoloji çalışmalarında çalışılan fenomene bağlı olarak katılımcı sayısı değişkenlik gösterebilir. Bazı kaynaklar fenomenolojik araştırmalarda katılımcı sayısının 5 ile 25 arasında olmasını önermektedir (Cresswell, 2013; Yıldırım \& Şimşek, 2013). Betimsel fenomenoloji çalışmalarında katılımcı sayısı yüksek sayıda tercih edilebilirken, yorumlayıcı fenomenoloji çalışmalarında derinlemesine araştırma yapılacağı için katılımcı sayısının düşük sayıda olması tercih edilmektedir. Literatürde yapılmış olan bazı fenomenolojik araştırmalarda katılımcı sayısının fazla sayıda tercih edildiği görülmüştür (Anderson \& Spencer, 2002; Topçuoğlu Ünal \& Tekin, 2013; Hasırc1, 2017; Özdemir \& Kaplan, 2017).

\section{Veri Toplama Aracı ve Süreci}

Çalışmada veri toplama aracı olarak araştırmacılar tarafından geliştirilmiş, matematik ögretmen adaylarının problem çözme ve matematiksel akıl yürütme konusundaki görüşlerinin derinlemesine incelenmesini amaçlayan yarı yapılandırılmış öğrenci görüşme formu kullanılmıştır. $\mathrm{Bu}$ formun kullanılmasının nedeni, derinlemesine bilgilere ulaşmayı (Büyüköztürk ve diğ., 2016) sağlamasından dolayıdır. Yapılan kapsamlı literatür taramasıyla birlikte araştırmanın amacına uygun 14 soruluk bir taslak form hazırlanmıştır. Taslak formdaki soruların araştırmanın amacına uygun olacak şekilde öğrenciler tarafindan kolay, anlaşılabilir ve cevaplanabilir olmasıyla birlikte yönlendirici ifadeleri bulundurmamasına dikkat edilmiştir. Bu form yapı geçerliği için matematik 
eğitimi ve nitel araştırma konusunda uzman iki öğretim elemanının görüşüne sunulmuştur. $\mathrm{Bu}$ süreçte uzmanların görüşlerinin değerlendirilmesi amacıyla, formdaki her soru için, "uygun", "kısmen uygun" ve "uygun değil" kategorilerinin bulunduğu uzman değerlendirme formu hazırlanmıştır. Bu formdan alınan dönütler doğrultusunda üç sorunun uygun olmadığına karar verilmiş ve formdan çıkarılmıştır. Ardından form pilot bir çalışmayla araştırma örneklemi dışında farklı yirmi iki matematik öğretmeni adayına uygulanmıştır. Bu süreçte dilbilgisi ve anlaşılırlık açısından uygun olmayan sorular düzeltilmiş ve 9 adet açık uçlu sorudan oluşan nihai yarı yapılandırılmış görüşme formu oluşturulmuştur. Görüşme formunda, öğretmen adaylarının problem, problem çözme, akıl yürütme becerisi, akıl yürütme oyunları ve akıl yürütme becerisinin önemi ve gerekliliği hakkındaki görüşlerini ortaya çıkarmak, problem çözme ve akıl yürütme becerisi arasındaki ilişki veya farka yönelik görüşlerini konu alan 9 adet açık uçlu soru yer almaktadır. Görüssme formu öğretmen adaylarına ders öğretim elemanının izni alındıktan sonra ders bitiminde sınıfta birinci araştırmacı tarafından uygulanmıştır.

\section{Verilerin Analizi}

Öğretmen adaylarından yazılı olarak alınan yanıtlar incelendiğinde iki öğretmen adayının konu ile ilgili cevaplar vermediği belirlenmiştir. Bu nedenle iki öğretmen adayının görüşleri araştırmanın dışında tutulmuştur. Elde edilen verilerin analizinde içerik analizi kullanılmıştır. İçerik analizi, elde edilen ham verilerin anlamlandırılarak belirli bir çerçeve oluşturulması ve beliren durum netlik kazandıktan sonra düzenlenerek kod ve kategorilerin ortaya çıkarak somutlaşmasını sağlamaktadır (Patton, 2002). Kod ve kategorilerin oluşturulmasında öncelikle dördüncü sınıf öğretmen adaylarının (yöneltilen sorulara daha ayrıntılı cevaplar verecekleri öngörüldüğünden), daha sonra 2 ve 3. sınıf öğretmen adaylarının görüşleri, araştırmacılar tarafından ayrı ayrı incelenerek karşılaşılabilecek kod ve kategoriler oluşturulmuştur. Analizlerin sonucunda araştırmacılar bir araya gelerek kod ve kategoriler karşılaştırılmış ve üzerinde farklı görüşlerin olduğu kod ve kategorilere son şekli verilmiştir. Miles ve Huberman (1994) benzeşen kodları "Görüş Birliği" ayrışan kodları ise "Görüş Ayrılığı" olarak adlandırmakta ve kodlayıcı güvenirliği için Uzlaşma Yüzdesi = Görüş Birliği / (Görüş Birliği + Görüş Ayrılığ 1$)$ * 100 formülünü önermektedir. Çalışmada araştırmacılar tarafindan elde edilen kodlara ait uzlaşma yüzdesi .79 olarak bulunmuştur. Miles-Huberman güvenirlik formülü değerinin .70 ve üzerinde olması, kodlamaların güvenilir olduğunu göstermektedir (Yıldırım \& Şimşek, 2013). Buna göre çalışmada araştırmacılar tarafından yapılan kodlamaların güvenilir olduğu görülmektedir. Bir öğretmen adayının herhangi bir soruya verdiği yanıt çoğunlukla bir kategoriye alınmakla birlikte birden fazla kategoriye de dâhil edilebilecek durumlarda oluşmuştur. Öğretmen adaylarından bir kısmı bazı soruları yanıtlamamıştır. Bu durum çalışmada "yanıt yok" kategorisi altında değerlendirilmiştir.

\section{Bulgular}

Öğretmen adaylarının problemin tanımına yönelik görüşlerini ortaya çıkarabilmek için "Sizce "Problem" nedir? Nasıl Tanımlarsınız?" sorusu yöneltilmiştir. Tablo 1'de katılımcıların görüşlerine yönelik oluşturulan kategoriler sunulmuştur. Katılımcıların verdikleri yanıtlar incelendiğinde görüşlerin 15 kategori altında toplandığı belirlenmiştir. Kategori sayıları sınıf bazında değerlendirildiğinde ikinci sınıftaki öğretmen adaylarının görüşlerinin 8 kategori altında, üçüncü sınıftakilerin 9 kategoride ve son olarak dördüncü sınıftaki öğretmen adaylarının görüşlerinin ise 15 kategori altında toplandığı belirlenmiştir. 
Tablo 1: Katılımcıların Problemin Tanımına Yönelik Görüşleri

\begin{tabular}{|c|c|c|c|c|}
\hline Kategoriler & İkinci sınıf & Üçüncü sınıf & Dördüncü sınıf & Toplam \\
\hline Sorun & $\% 29$ & $\% 35$ & $\% 23$ & $\% 28$ \\
\hline Çözüm bekleyen eylem, durum & $\% 23$ & $\% 22$ & $\% 17$ & $\% 20$ \\
\hline Güçlük, zorluk & $\% 18$ & $\% 8$ & $\% 10$ & $\% 12$ \\
\hline Yanıtı bulunması gereken soru & $\% 12$ & $\% 8$ & $\% 3$ & $\% 7$ \\
\hline Belirsiz durum & $\% 6$ & - & $\% 8$ & $\% 5$ \\
\hline $\begin{array}{l}\text { Günlük hayat durumlarının } \\
\text { matematiksel ifadesi }\end{array}$ & - & - & $\% 10$ & $\% 5$ \\
\hline Rutin olmayan durum & - & $\% 5$ & $\% 7$ & $\% 5$ \\
\hline Belirsiz durum & $\% 6$ & - & $\% 8$ & $\% 5$ \\
\hline Aşılması gereken engel & $\% 3$ & $\% 8$ & $\% 5$ & $\% 5$ \\
\hline Düşündürmeye yarayan etkinlik & - & $\% 5$ & $\% 1.5$ & $\% 2$ \\
\hline $\begin{array}{l}\text { Çözüldüğünde sonuçlara götüren } \\
\text { durum }\end{array}$ & - & $\% 5$ & $\% 1.5$ & $\% 2$ \\
\hline Kriz & - & - & $\% 1.5$ & $\% 1$ \\
\hline Tartışma & - & - & $\% 1.5$ & $\% 1$ \\
\hline Mekanizmadaki aksaklıklar & $\% 3$ & - & $\% 1.5$ & $\% 1$ \\
\hline Sınama soruları & - & $\% 4$ & $\% 1.5$ & $\% 1$ \\
\hline TOPLAM & $\% 100$ & $\% 100$ & $\% 100$ & $\% 100$ \\
\hline
\end{tabular}

Tablo 1'e göre katılımcılar Sizce problem nedir? Nasıl tanımlarsınız? sorusuna büyük çoğunlukla "çözüm bekleyen eylem / durum" ve "sorun" șeklinde cevap vermișlerdir. Katılımciların bir kısmı da problemin "belirsiz durum", "güçlük, zorluk", "rutin olmayan durum", "yanıtı bulunması gereken soru" ve "aşılması gereken engel" olduğunu belirtmişlerdir. Katılımcıların çok az bir kısmı da probleme "kriz", "tartışma", "mekanizmadaki aksaklıklar", "çözüldüğünde sonuçlara götüren durum", "günlük hayat durumlarının matematiksel ifadesi", "düşündürmeye yarayan etkinlik" ve "sınama soruları" demektedir. Aşağıda sırasıyla en çok tekrarlanan ilk üç kategori olan "çözüm bekleyen eylem/durum", "sorun" ve "güçlük, zorluk" kategorilerine örnek ifadelere yer verilmiştir.

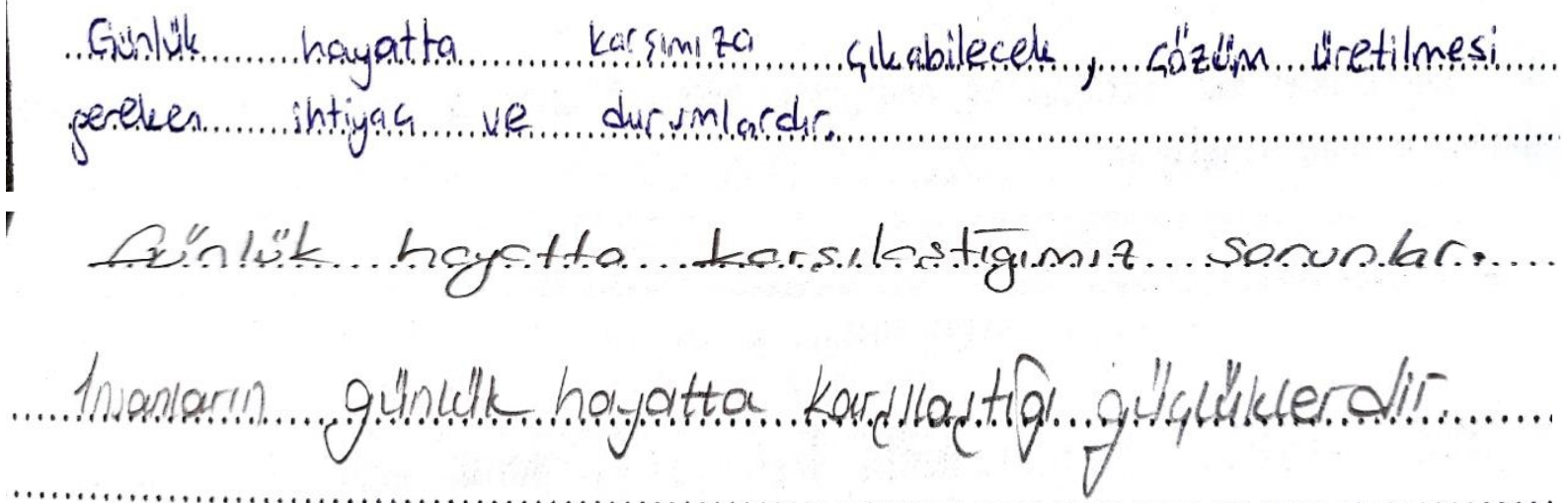

Katılımcıların matematikte problem çözmeye ne anlam yüklediklerini anlamak amacıyla "Matematikte problem çözme sizin için ne anlam ifade ediyor?" şeklinde soru yöneltilmiştir. Katılımcıların verdikleri yanıtlar incelendiğinde görüşlerin 18 kategori altında toplandığ belirlenmiştir. Alınan yanıtlar incelendiğinde ikinci sınıflarda 13 kategori altında, üçüncü sınıflarda 11 kategori altında ve dördüncü sınıflarda 18 kategori olmak üzere toplam 18 kategori altında toplandığ 1 tespit edilmiştir. Tablo 2 'de katılımcıların görüşlerine yönelik oluşturulan kategoriler sunulmuştur. 


\begin{tabular}{|c|c|c|c|c|}
\hline Kategoriler & $\begin{array}{c}\text { İkinci } \\
\text { Sınıf }\end{array}$ & Üçüncü sınıf & $\begin{array}{c}\text { Dördüncü } \\
\text { sınıf }\end{array}$ & Toplam \\
\hline Matematiksel ifadelerle çözmek & $\% 20$ & $\% 25$ & $\% 16$ & $\% 19$ \\
\hline Çözüme ulaşmak & $\% 11$ & $\% 17$ & $\% 22$ & $\% 17$ \\
\hline Sorunların çözülmesi & $\% 20$ & - & $\% 12$ & $\% 11$ \\
\hline $\begin{array}{l}\text { Günlük hayat problemlerinin sayısal olarak } \\
\text { çözümü }\end{array}$ & $\% 8$ & $\% 13$ & $\% 8$ & $\% 9$ \\
\hline Verilen soruyu çözmek & $\% 8$ & $\% 8$ & $\% 8$ & $\% 8$ \\
\hline Akıl yürütmek & $\% 6$ & $\% 13$ & $\% 2$ & $\% 5$ \\
\hline Matematiği özümsemek & $\% 3$ & - & $\% 6$ & $\% 4$ \\
\hline Yaşamın parçası & $\% 3$ & $\% 4$ & $\% 4$ & $\% 4$ \\
\hline Soyut düşünceyi somut düşünceye dönüştürmek & - & $\% 4$ & $\% 4$ & $\% 3$ \\
\hline Hayatı anlaşılır hale getirmek & $\% 3$ & $\% 4$ & $\% 2$ & $\% 3$ \\
\hline Yeni yollar bulmak & $\% 6$ & - & $\% 2$ & $\% 3$ \\
\hline Mantıksal işlem & $\% 6$ & - & $\% 2$ & $\% 3$ \\
\hline Beyin firtınası yapmak & - & $\% 4$ & $\% 4$ & $\% 2$ \\
\hline Mutluluk & - & $\% 4$ & $\% 2$ & $\% 2$ \\
\hline Sayılarla mücadele & $\% 3$ & - & $\% 2$ & $\% 2$ \\
\hline Bilgi ve becerinin gelişmesi & - & $\% 4$ & $\% 2$ & $\% 2$ \\
\hline Mevcut bilgileri kullanabilme & $\% 3$ & - & $\% 2$ & $\% 2$ \\
\hline Dört işlem değildir & - & - & $\% 2$ & $\% 1$ \\
\hline TOPLAM & $\% 100$ & $\% 100$ & $\% 100$ & $\% 100$ \\
\hline
\end{tabular}

Tablo 2 incelendiğinde, katılımcıların problem çözmeyi çoğunlukla "matematiksel ifadelerle çözmek" ve "çözüme ulaşmak" olarak gördükleri ortaya çıkmıştır. Katılımcıların ifadeleri sınıflara göre değerlendirildiğinde ikinci sinıftaki ögrencilerin matematikte problem çözme için sorunların çözülmesi ve matematiksel ifadelerle çözmek olduğunu ifade etmişlerdir. Üçüncü ve dördüncü sinıftaki ögrencilerin ise "matematiksel ifadelerle çözmek" ve "çözüme ulaşmak" kavramlarını anladıkları görülmektedir. Aşağıda sırasıyla en çok tekrarlanan ilk üç kategori olan "matematiksel ifadelerle çözmek" , "çözüme ulaşmak" ve "sorunların çözülmesi" kategorileri için örnek ifadeler sunulmuştur.
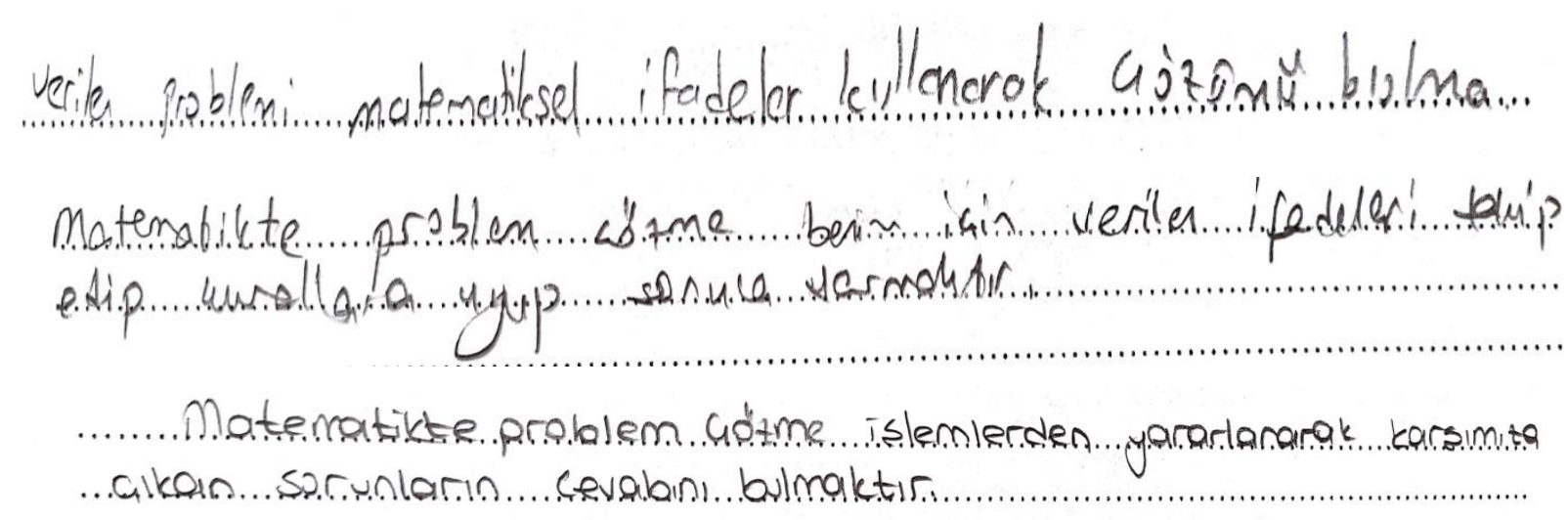

Katılımc1ların matematiksel akıl yürütmeye hangi anlamı yüklediklerini öğrenebilmek amaciyla "Bir matematikçi gözüyle matematiksel akl yürütme sizin için ne anlam ifade ediyor?" sorusu sorulmuştur. Yanıtlar incelendiğinde çok sayıda görüş olduğu tespit edilmiştir. Alınan yanıtlar ikinci sınıfta 11 kategori altında, üçüncü sınıflarda 14 kategori altında ve dördüncü sınıflarda 22 kategori olmak üzere toplam 22 kategori altında toplandığı belirlenmiştir. Tablo 3’te katılımcıların görüşlerine yönelik oluşturulan kategoriler sunulmuştur. 
Tablo 3: Matematiksel Akıl Yürütme Hakkındaki Görüşler

\begin{tabular}{|c|c|c|c|c|}
\hline Kategoriler & $\begin{array}{c}\text { İkinci } \\
\text { sinıf }\end{array}$ & $\begin{array}{c}\begin{array}{c}\text { Üçüncü } \\
\text { sınıf }\end{array} \\
\end{array}$ & $\begin{array}{c}\text { Dördüncü } \\
\text { sinıf }\end{array}$ & Toplam \\
\hline Matematiği kullanarak cevaplamak & $\% 28$ & $\% 3$ & $\% 16$ & $\% 16$ \\
\hline Fikir ve düşünme becerisi geliştirme & $\% 19$ & $\% 22$ & $\% 8$ & $\% 14$ \\
\hline Çözüm yolları üretmek & $\% 10$ & $\% 18$ & $\% 8$ & $\% 11$ \\
\hline Probleme matematiksel bir mantıkla yaklaşma & $\% 16$ & $\% 18$ & $\% 4$ & $\% 11$ \\
\hline Mantıksal düşünme & $\% 6$ & $\% 3$ & $\% 9$ & $\% 7$ \\
\hline Matematiksel düşünceyle tutarlı olarak yorum yapma & $\% 6$ & $\% 12$ & $\% 3$ & $\% 6$ \\
\hline Problemin sistematik çözülmesini sağlar & $\% 3$ & $\% 3$ & $\% 8$ & $\% 5$ \\
\hline Akıl yürütme & - & - & $\% 6$ & $\% 3$ \\
\hline Günlük yaşamda olaylara farklı bakabilme & - & - & $\% 6$ & $\% 3$ \\
\hline Problemi çözme stratejisi & $\% 3$ & $\% 3$ & $\% 3$ & $\% 3$ \\
\hline Var olan önermelerden yeni önermeler & $\% 3$ & & $\% 3$ & $\% 2$ \\
\hline Soyut kavramları daha iyi ifade edebilme & - & $\% 3$ & $\% 3$ & $\% 2$ \\
\hline Problemi anlaşılır hale getirmek & - & $\% 3$ & $\% 3$ & $\% 2$ \\
\hline Matematik okuryazarlığı & - & - & $\% 3$ & $\% 2$ \\
\hline Durumlara, olaylara analitik düşünmeyle yaklaşmak & - & $\% 3$ & $\% 3$ & $\% 2$ \\
\hline Ayrıntılarla irdelemek & - & $\% 3$ & $\% 2$ & $\% 2$ \\
\hline Matematik ifadeleri arasında ilişki kurma & - & $\% 3$ & $\% 2$ & $\% 2$ \\
\hline Güçlüklerin üstesinden gelebilmek & $\% 3$ & - & $\% 2$ & $\% 2$ \\
\hline Yanit yok & $\% 3$ & $\% 3$ & $\% 2$ & $\% 2$ \\
\hline Tahmin etme & - & - & $\% 2$ & $\% 1$ \\
\hline Olmayana ergi & - & - & $\% 2$ & $\% 1$ \\
\hline İstatistiksel çözüm arama & - & - & $\% 2$ & $\% 1$ \\
\hline TOPLAM & $\% 100$ & $\% 100$ & $\% 100$ & $\% 100$ \\
\hline
\end{tabular}

Tablo 3'e göre katılımcıların matematiksel akıl yürütme ile ilgili görüşleri "matematiği kullanarak cevaplamak" ve "fikir ve düşünme becerisi geliştirme" kategorilerinde yoğunlaşmaktadır. Görüşler sınıflar bazında değerlendirildiğinde ikinci ve dördüncü sınıftaki öğrenciler "matematiği kullanarak cevaplamak" kategorisinde görüşe sahiptirler. Üçüncü sınıftaki öğrencilerin verdiği yanıtlar incelendiğinde ise diğer sınıflardan farklı olarak en fazla "fikir ve düşünme becerisi geliştirme" kategorisinde görüş belirtmişlerdir. Arıca bazı katılımcılar akıl yürütme hakkında görüş belirtmemiştir. Aşağıda sırasıyla en çok tekrarlanan ilk dört kategori olan "matematiği kullanarak cevaplamak", "fikir ve düşünme becerisi geliştirme", "probleme matematiksel bir mantıkla yaklaşma" ve "çözüm yolları üretmek" kategorileri için örnek ifadeler sunulmuştur.
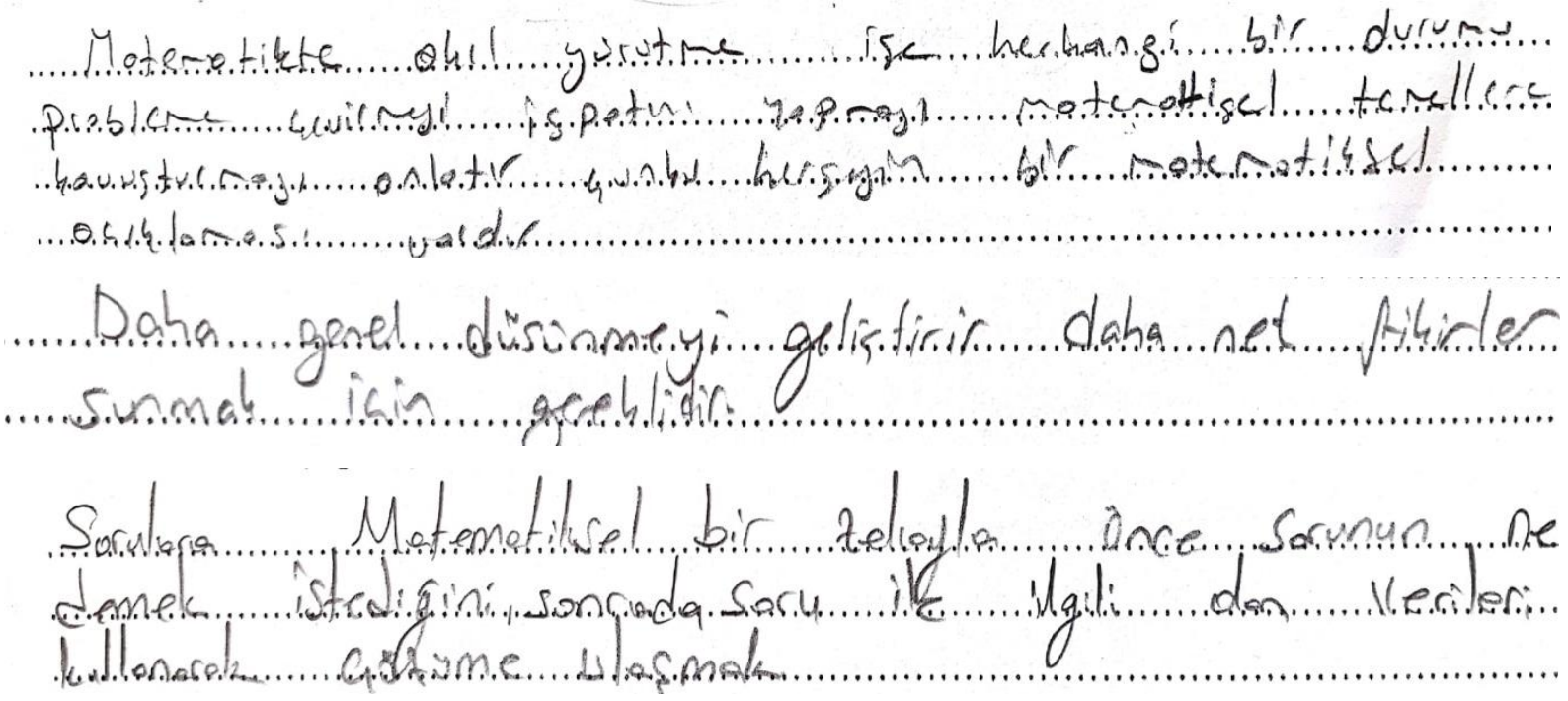


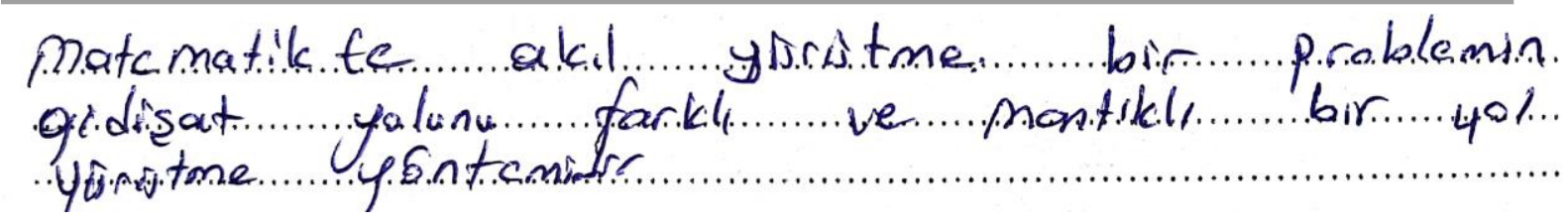

Katılımcıların lisans öğrenimleri boyunca matematiksel akıl yürütme hakkında eğitim alıp almadıklarını anlamak amacıyla katılımcılara "Matematiksel Akıl Yürütme hakkında lisans ögrenimi süresince verilen eğitimler konusundaki düsünceleriniz nelerdir? Açıklayınız?" şeklinde soru yöneltilmiştir. Alınan yanıtlar ikinci sınıflarda 8, üçüncü sınıflarda 7 ve dördüncü sınıflarda 10 olmak üzere toplamda 10 kategori altında toplanmıştır. Tablo 4'de söz konusu kategorilere yer verilmiştir.

Tablo 4: Lisans Öğreniminde Verilen Eğitimlere Yönelik Görüşler

\begin{tabular}{lcccc}
\hline Kategoriler & $\begin{array}{c}\text { İkinci } \\
\text { sınıf }\end{array}$ & Üçüncü sınıf & $\begin{array}{c}\text { Dördüncü } \\
\text { sınıf }\end{array}$ & Toplam \\
\hline Yeterli değil & $\% 30$ & $\% 29$ & $\% 34$ & $\% 30$ \\
Gerekli ve önemli & $\% 27$ & $\% 26$ & $\% 7$ & $\% 18$ \\
Teorik ağırlıklı & $\% 16$ & $\% 11$ & $\% 13$ & $\% 13$ \\
Yeterli & $\% 8$ & $\% 17$ & $\% 7$ & $\% 10$ \\
Yanıt yok & $\% 10$ & $\% 6$ & $\% 11$ & $\% 10$ \\
Daha anlaşılır ve açık eğitim verilmeli & $\% 3$ & $\% 8$ & $\% 6$ & $\% 6$ \\
Eğitim almadım & $\% 3$ & - & $\% 10$ & $\% 5$ \\
Matematik daha çok yer almalı & $\% 3$ & - & $\% 6$ & $\% 3$ \\
Seçmeli dersler etkili oldu & - & - & & $\% 2$ \\
Analitik düşünme bakış açısıyla anlatıldı & - & $\% 3$ & $\% 4$ & $\% 2$ \\
Sistematik şekilde ele alınmalı & - & - & $\% 2$ & $\% 1$ \\
\hline TOPLAM & $\% 100$ & $\% 100$ & $\% 100$ & $\% 100$ \\
\hline
\end{tabular}

Tablo 4 incelendiğinde genel olarak katılımcılar, matematiksel akıl yürütme ile ilgili olarak yeterli eğitim almadıkları görüşündedirler. Diğer yandan katılımcıların yüzde \%18'lik kısmı matematiksel akıl yürütmenin gerekli ve önemli olduğuna değinmiştir. Çok az bir kısmı aldıkları derslerden memnun kaldığını belirtmişlerdir. Söz konusu kategoriler "yeterli", "seçmeli dersler etkili oldu", analitik düşünme bakış açısıyla anlatıldı" ve "sistematik şekilde ele alındı" olarak tespit edilmiştir. Aşağıda sırasıyla en çok tekrarlanan ilk üç kategori olan "yeterli değil", "gerekli ve önemli" ve "teorik ağırlıklı" kategorilerinin oluşmasını sağlayan ifadelere yer verilmiştir.
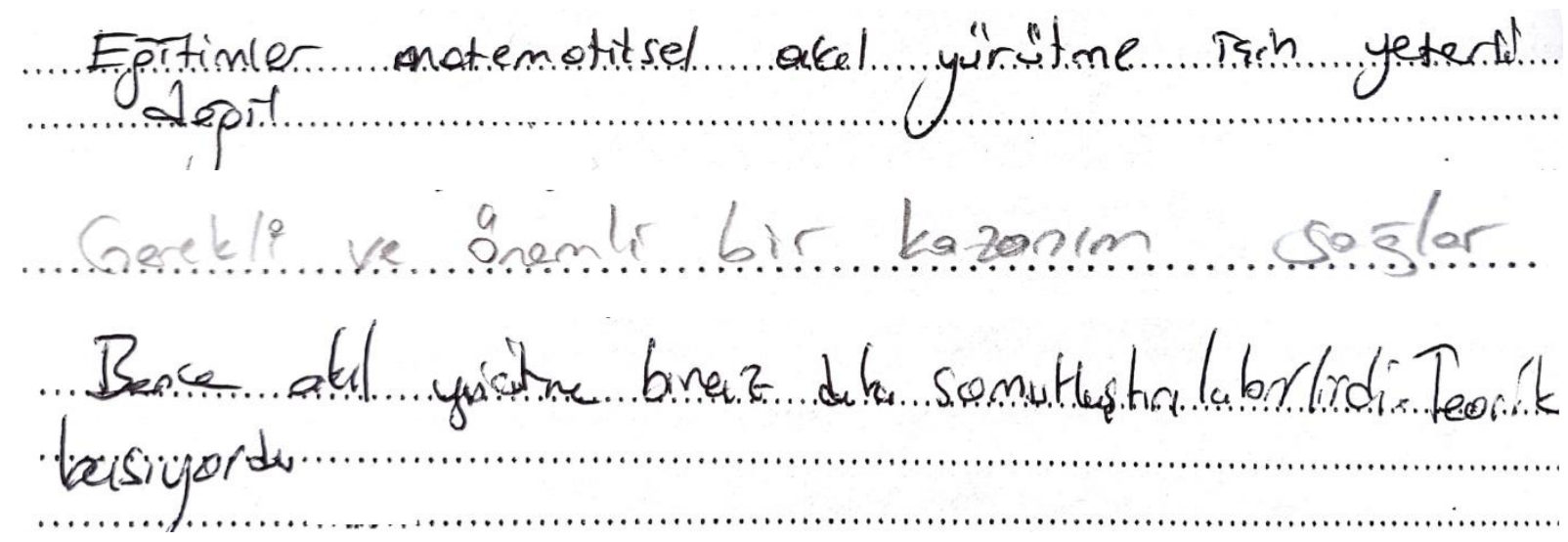

Katılımcıların matematiksel akıl yürütme ile problem çözme arasındaki ilişkiye yönelik görüşlerini anlamak amaciyla "Sizce "Matematiksel Akll Yürütme" ile "Problem Çözme" arasında nasil bir ilişki vardır?" sorusu sorulmuştur. Sorulan soruya verilen yanıtların ikinci sınıflarda 9, üçüncü sinıflarda 7 ve dördüncü sinıflarda 8 olmak üzere toplamda 8 kategori altında toplandığı belirlenmiştir. Tablo 5'da bu kategorilere yer verilmiştir. 
Tablo 5: Matematiksel Akıl Yürütme ile Problem Çözme Arasındaki İlişkiye Yönelik Görüşler

\begin{tabular}{|c|c|c|c|c|}
\hline Kategoriler & $\begin{array}{c}\text { İkinci } \\
\text { Sinıf }\end{array}$ & Üçüncü sınıf & $\begin{array}{c}\text { Dördüncü } \\
\text { sinıf }\end{array}$ & Toplam \\
\hline $\begin{array}{l}\text { Problem çözme işlemi gerçekleşirken matematiksel } \\
\text { akıl yürütme kullanılır }\end{array}$ & $\% 24$ & $\% 34$ & $\% 28$ & $\% 28$ \\
\hline Ayrılmaz bir bütündür & $\% 28$ & $\% 30$ & $\% 22$ & $\% 25$ \\
\hline $\begin{array}{l}\text { Problem çözme sürecinde akıl yürütme kullanılırsa } \\
\text { daha aktif ve daha hızlı olunur }\end{array}$ & $\% 21$ & $\% 8$ & $\% 20$ & $\% 17$ \\
\hline $\begin{array}{l}\text { Akıl yürütme araçtır, problem çözme sürecinden } \\
\text { kullanılan yöntemdir }\end{array}$ & $\% 9$ & $\% 12$ & $\% 13$ & $\% 11$ \\
\hline $\begin{array}{l}\text { Akıl yürütme probleme farklı açıdan bakma ve } \\
\text { farklı metotlar geliştirmektir }\end{array}$ & $\% 6$ & $\% 8$ & $\% 9$ & $\% 8$ \\
\hline $\begin{array}{l}\text { Problem çözmede somut bir işlem ele alınır ancak } \\
\text { akıl yürütmede soyut düşünme ön plandadır }\end{array}$ & $\% 3$ & $\% 4$ & $\% 4$ & $\% 4$ \\
\hline Akıl yürütme gidiş yolu, problem çözme sonuç & $\% 3$ & $\% 4$ & $\% 4$ & $\% 4$ \\
\hline Yanit yok & $\% 3$ & - & $\% 2$ & $\% 2$ \\
\hline $\begin{array}{l}\text { Problem çözmede soyut düşünme ön plandadır } \\
\text { ancak akıl yürütmede somut bir işlem ele alınır }\end{array}$ & $\% 3$ & - & - & $\% 1$ \\
\hline TOPLAM & $\% 100$ & $\% 100$ & $\% 100$ & $\% 100$ \\
\hline
\end{tabular}

Tablo 5 incelendiğinde katılımcıların çoğunun problem çözme işlemi gerçekleşirken matematiksel akıl yürütme kullanılır ve ayrılmaz bir bütündür görüşüne sahip oldukları görülmüştür. Yani katılımcıların büyük bir çoğunluğu matematiksel akıl yürütme ile problem çözme arasında bir ilişkinin olduğunu belirtmişlerdir. Aşağıda sırasıyla en çok tekrarlanan ilk 3 kategori olan "Problem Çözme İşlemi Gerçekleşirken Matematiksel Akıl Yürütme Kullanılır”, “Ayrılmaz Bir Bütündür” ve "Problem Çözme Sürecinde Akıl Yürütme Kullanılırsa daha Aktif ve Daha Hızlı Olunur" kategorilerine örnek ifadelere yer verilmiştir.

Biz...... problobern L̈̈zenen

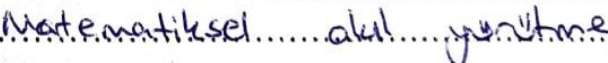
y. Hotcmine ......... baskurur.uz...

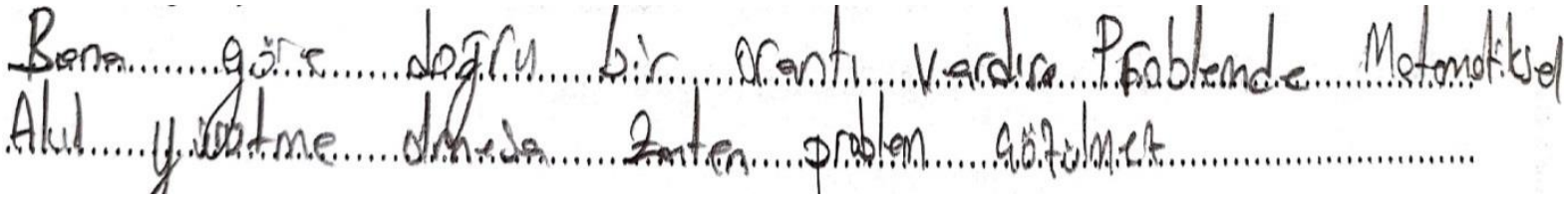

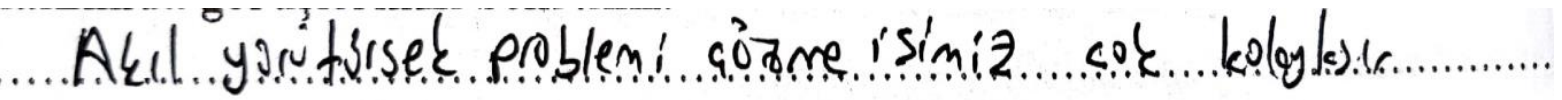

Katılımcıların akıl yürütme oyunları hakkında bilgi sahibi olup olmadıklarını belirleyebilmek için onlara "Akll Yürütme Oyunları hakkında bilginiz var mı? Hangi oyunları örnek verebilirsiniz?" sorusu yöneltilmiştir. Katılımcıların yanıtları ikinci sınıflarda 7, üçüncü sınıflarda 7 ve dördüncü 17 olmak üzere toplam 17 kategori altında toplandığı belirlenmiş̦tir. Tablo 6'de söz konusu kategorilere yer verilmiştir. 


\begin{tabular}{|c|c|c|c|c|}
\hline \multicolumn{5}{|c|}{ Tablo 6: Katılımcıların Akı1 Yürütme Oyunlarına Yönelik Görüșleri } \\
\hline Kategoriler & İkinci sınıf & Üçüncü sınıf & Dördüncü sınıf & Toplam \\
\hline Satranç & $\% 41$ & $\% 30$ & $\% 36$ & $\% 35$ \\
\hline Yanit yok & $\% 23$ & $\% 27$ & $\% 25$ & $\% 25$ \\
\hline Sudoku & $\% 15$ & $\% 7$ & $\% 9$ & $\% 10$ \\
\hline Dama & $\% 9$ & $\% 7$ & $\% 4$ & $\% 6$ \\
\hline Tavla & - & $\% 10$ & $\% 4$ & $\% 5$ \\
\hline Briç & - & $\% 16$ & $\% 1.5$ & $\% 5$ \\
\hline Tangram & - & - & $\% 4$ & $\% 2$ \\
\hline Zeka Küрü & $\% 6$ & - & $\% 1.5$ & $\% 2$ \\
\hline Yapboz & $\% 3$ & $\% 3$ & $\% 1.5$ & $\% 2$ \\
\hline Lego & - & - & $\% 1.5$ & $\% 1$ \\
\hline Mangala & - & - & $\% 1.5$ & $\% 1$ \\
\hline Mental oyunlar & - & - & $\% 1.5$ & $\% 1$ \\
\hline Zeka oyunları & $\% 3$ & - & $\% 1.5$ & $\% 1$ \\
\hline Dokuz taş & - & - & $\% 3$ & $\% 1$ \\
\hline Bulmaca & - & - & $\% 1.5$ & $\% 1$ \\
\hline Eşleştirme & - & - & $\% 1.5$ & $\% 1$ \\
\hline Kule & - & - & $\% 1.5$ & $\% 1$ \\
\hline TOPLAM & $\% 100$ & $\% 100$ & $\% 100$ & $\% 100$ \\
\hline
\end{tabular}

Tablo 6 incelendiğinde, katılımcıların büyük çoğunluğunun akıl yürütme oyunu olarak satranç örneğini verdikleri görülmüştür. Diğer yandan yüzde $25^{\prime}$ lik bölümü bu soruya yanıt verememiştir. Sınıflar bazında değerlendirildiğinde dördüncü sınıftaki öğrencilerin akıl yürütme oyunları hakkında daha çok bilgiye sahip oldukları açıkça görülmektedir. Aşağıda sırasıyla en çok tekrarlanan ilk üç kategori olan "Satranç", "sudoku" ve "dama" kategorilerine ait örnek ifadelere yer verilmiştir.

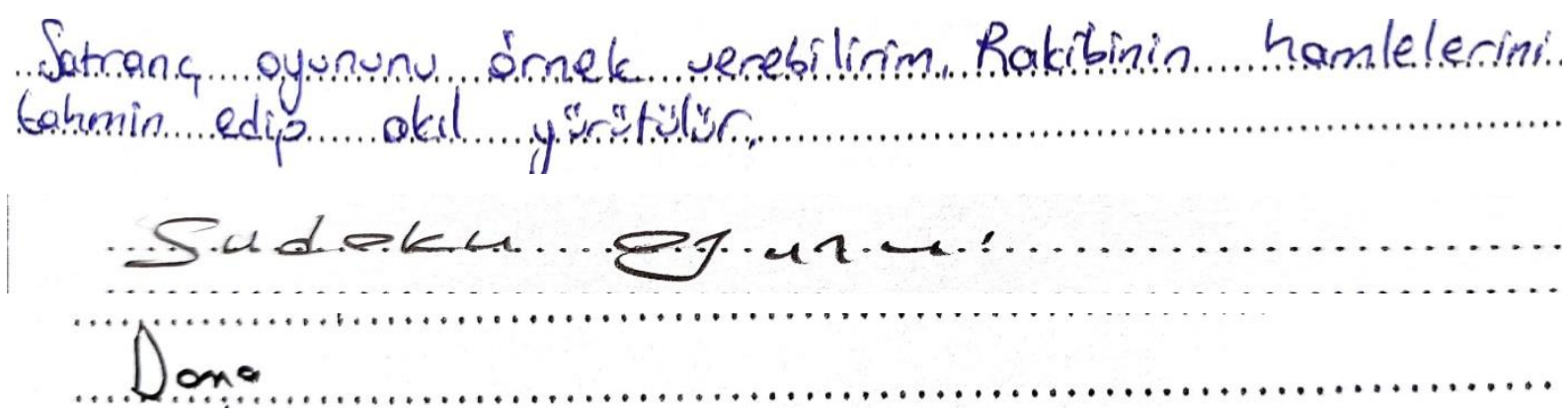

Katılımcıların matematiksel akıl yürütmenin MEB ortaokul programlarında yer alıp almaması hususunda görüşlerini alabilmek için "Sizce "Matematiksel akıl yürütme becerisi" MEB matematik ögretim müfredatında yer almalı mıdır? Neden açıklayınız?” Sorusu sorulmuştur. Sorulan soruya verilen yanıtların ikinci sınıflarda 14, üçüncü sınıflarda 14 ve dördüncü sınıflarda 20 olmak üzere toplamda 22 kategori altında toplandığı belirlenmiştir. Tablo 7'de bu kategorilere yer verilmiştir. 
Tablo 7: Matematiksel Akı1 Yürütmenin Öğretim Müfredatında Yer Alması/maması Hakkındaki Görüşler

\begin{tabular}{|c|c|c|c|c|}
\hline Kategoriler & $\begin{array}{c}\text { İkinci } \\
\text { sınıf }\end{array}$ & $\begin{array}{c}\text { Üçüncü } \\
\text { sınıf }\end{array}$ & $\begin{array}{l}\text { Dördüncü } \\
\text { sınıf }\end{array}$ & Toplam \\
\hline $\begin{array}{l}\text { Evet, çünkü hayatımızın her alanında karşımıza } \\
\text { cıkar, ihtivac duyarız }\end{array}$ & $\% 13$ & $\% 12$ & $\% 11$ & $\% 12$ \\
\hline Evet, düşünme becerisi kazandırır & $\% 16$ & $\% 3$ & $\% 11$ & $\% 10$ \\
\hline Evet, matematiğe olan ilgi ve tutumu artırır & $\% 13$ & $\% 17$ & $\% 3$ & $\% 9$ \\
\hline $\begin{array}{l}\text { Evet, erken yaşta verilmesi gerekir. Çünkü ağaç } \\
\text { yaşken eğilir }\end{array}$ & $\% 16$ & $\% 12$ & $\% 2$ & $\% 8$ \\
\hline Evet, problemi daha hızlı ve etkili çözmeyi sağlar & $\% 3$ & $\% 9$ & $\% 8$ & $\% 7$ \\
\hline Evet, yaratıcılık ve hayal gücü geliştirir & $\% 6$ & $\% 6$ & $\% 8$ & $\% 7$ \\
\hline Evet, zihinsel gelişim sağlar & $\% 6$ & $\% 9$ & $\% 5$ & $\% 6$ \\
\hline Evet, ezbercilikten kurtarır & - & $\% 14$ & $\% 5$ & $\% 6$ \\
\hline Problem çözme isteğini, merak duygusunu artırır & $\% 3$ & $\% 3$ & $\% 5$ & $\% 4$ \\
\hline $\begin{array}{l}\text { Evet, olaylara ve problemlere farklı bakabilme } \\
\text { olanağı sunar }\end{array}$ & $\% 9$ & - & $\% 5$ & $\% 5$ \\
\hline $\begin{array}{l}\text { Evet, çünkü matematik yalnızca işlemden ibaret } \\
\text { değildir }\end{array}$ & - & $\% 3$ & $\% 9$ & $\% 5$ \\
\hline Evet, ilgi çekecek oyunlara yer verilmeli & - & - & $\% 8$ & $\% 4$ \\
\hline $\begin{array}{l}\text { Evet, mantık yürütme becerilerini etkin kullanmayı } \\
\text { sağlar }\end{array}$ & $\% 3$ & $\% 3$ & $\% 3$ & $\% 3$ \\
\hline Yanit yok & $\% 3$ & $\% 3$ & $\% 2$ & $\% 2$ \\
\hline $\begin{array}{l}\text { Farklı yöntem ve teknikler kullanmaya olanak } \\
\text { sağlar }\end{array}$ & - & - & $\% 5$ & $\% 2$ \\
\hline Evet, girişimci bireyler yetiştirir & $\% 3$ & - & $\% 3$ & $\% 2$ \\
\hline Evet, psikomotor becerileri geliştirir & $\% 3$ & - & $\% 2$ & $\% 2$ \\
\hline $\begin{array}{l}\text { Hayır; ders olarak verilmesine gerek yok, derslerin } \\
\text { işlenişinde kullanılsın }\end{array}$ & $\% 3$ & - & $\% 3$ & $\% 2$ \\
\hline Evet, öğrenmeyi kolaylaştırır & - & - & $\% 2$ & $\% 1$ \\
\hline Daha eğlenceli, daha anlamlı & - & - & $\% 2$ & $\% 1$ \\
\hline $\begin{array}{l}\text { Hayır, öğrenciler hayal dünyasına kendilerini } \\
\text { kaptırıyor }\end{array}$ & - & $\% 3$ & - & $\% 1$ \\
\hline $\begin{array}{l}\text { Sayısal yeteneği olanlar için yer almalı fakat sözel } \\
\text { yeteneği olanlar için faydalı olmayabilir }\end{array}$ & - & $\% 3$ & . & $\% 1$ \\
\hline TOPLAM & $\% 100$ & $\% 100$ & $\% 100$ & $\% 100$ \\
\hline
\end{tabular}

Tablo 7 incelendiğinde çok sayıda kategori olduğu görülmüştür. Bu durum katılımcı görüşlerinin çeşitli olduğunu göstermektedir. Katılımcıların büyük bir bölümü "Evet, çünkü hayatımızın her alanında karşımıza çıkar, ihtiyaç duyarız", "Evet, düşünme becerisi kazandırı»", "Evet, matematiğe olan ilgi ve tutumu artırır" ve "Evet, erken yaşta verilmesi gerekir. Çünkü ağaç yaşken eğilir" görüşüne sahip oldukları görülmüştür. Katılımcıların bir kısmı da bu soruya yanıt vermemiştir. Sınıflar bazında değerlendirme yapıldığında ikinci sınıf öğrencilerinde "Evet, düşünme becerisi kazandırır" ve "Evet, erken yaşta verilmesi gerekir. Çünkü ağaç yaşken eğilir" kategorileri ön plana çıkarken üçüncü sınıflarda "Evet, matematiğe olan ilgi ve tutumu artırır" görüşü ile dördüncü sınıflarda "Evet, çünkü hayatımızın her alanında karşımıza çıkar, ihtiyaç duyarız" görüşü ön plana çıkmıştır. Aşağıda sırasıyla en çok tekrarlanan ilk 3 kategori olan "Evet, çünkü hayatımızın her alanında karşımıza çıkar, ihtiyaç duyarız", "Evet, düşünme becerisi kazandırır" ve "Evet, matematiğe olan ilgi ve tutumu artırır" kategorilerine örnek ifadelere yer verilmiştir.

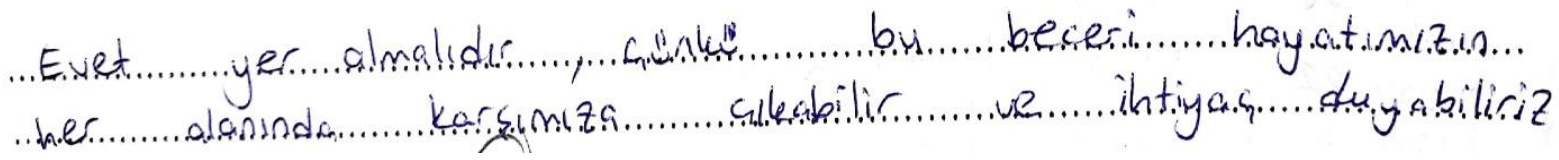




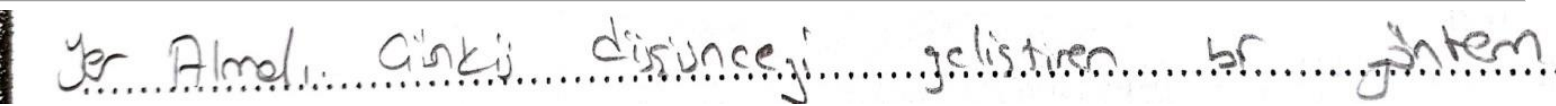

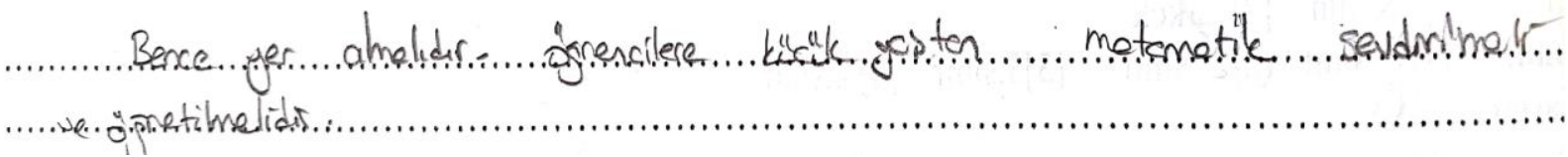

Katılımcıların matematiksel akı1 yürütme ile matematik başarısı arasındaki ilişkiye yönelik görüşlerini anlamak amacıyla katılımcılara "Matematiksel akıl yürütme ve matematik başarısı arasında nasıl bir iliş̧ki olduğunu düşünüyorsunuz? Açıklayınız.” şeklinde soru yöneltilmiştir. Alınan yanıtlar ikinci, üçüncü ve dördüncü sınıflarda 4 ve toplamda 6 kategori altında toplanmıştır. Tablo 8 'de söz konusu kategorilere yer verilmiştir.

Tablo 8: Matematiksel Akıl Yürütme ile Matematik Başarısı Arasındaki İlişkiye Yönelik Görüşler

\begin{tabular}{lcccc}
\hline Kategoriler & $\begin{array}{c}\text { İkinci } \\
\text { sınıf }\end{array}$ & $\begin{array}{c}\text { Üçüncü } \\
\text { sınıf }\end{array}$ & $\begin{array}{c}\text { Dördüncü } \\
\text { sınıf }\end{array}$ & Toplam \\
\hline Akıl yürütme matematik başarısını artırır & $\% 84$ & $\% 88$ & $\% 88$ & $\% 87$ \\
Yanıt yok & $\% 10$ & $\% 4$ & $\% 6$ & $\% 6$ \\
İlişki vardır ancak matematik zekâsına daha çok & $\% 3$ & $\% 4$ & $\% 2$ & $\% 3$ \\
güveniyorum & & & $\% 4$ & $\% 2$ \\
Yoktur, başarı geçici akıl yürütme kalıcıdır & - & - & $\% 1$ & $\% 1$ \\
Akıl yürüitme düşünme tarzı, başarı sonuç & $\mathbf{\%}$ & - & - & $\% 1$ \\
Zıt ilişki vardır & - & $\% 4$ & - & $\% 100$ \\
\hline Toplam & $\% 100$ & $\% 100$ & $\% 100$ & $\% 100$ \\
\hline
\end{tabular}

Tablo 8 incelendiğinde katılımcıların büyük bir çoğunluğunun "akıl yürütme matematik başarısını artırır" yönünde görüş belirttiği tespit edilmiştir. Diğer yandan yüzde 6'lık bir kısım yanıt vermemiştir. Ayrıca az sayıda katılımcı ilişkinin olmadığı ve zıt yönde ilişki olduğu görüşünü verdikleri görülmektedir. Aşağıda en çok tekrarlanan "akıl yürütme matematik başarısını artırır" kategorisinin oluşmasını sağlayan ifadelere yer verilmiştir.

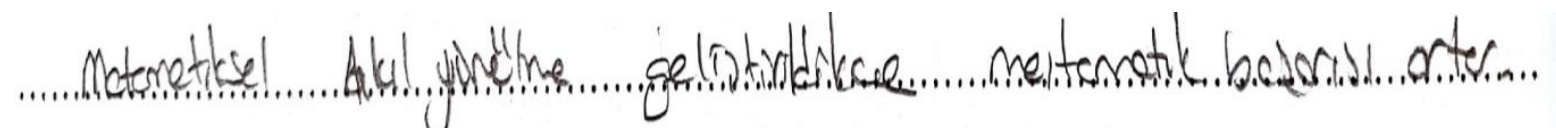

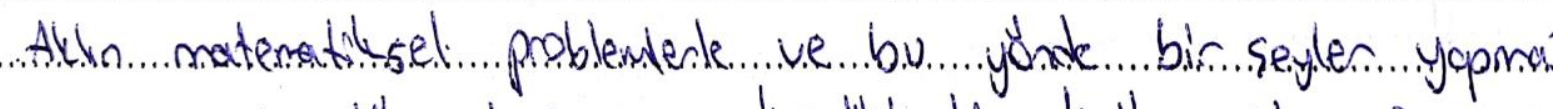

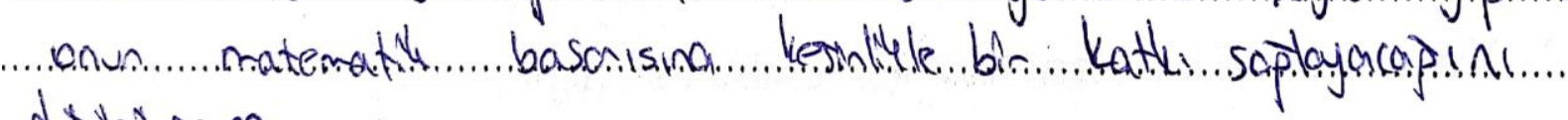
ditiviform

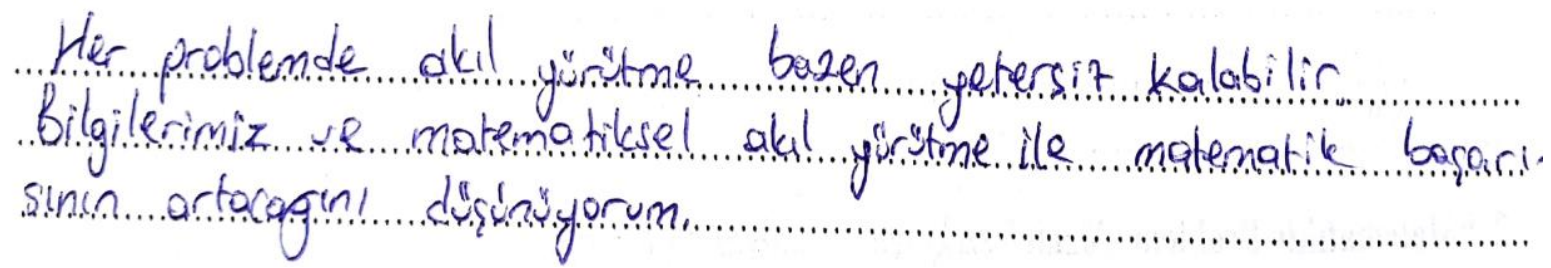

Katılımcıların matematikte (ortaokul öğretim faaliyetlerinde) gerekli olan akıl yürütme türleri hakkındaki görüşlerini belirleyebilmek için onlara "Sizce matematikte (ortaokul ögretim faaliyetlerinde) gerekli olan akıl yürütme türleri nelerdir? Bu akl yürütme türleri hakkındaki düşüncelerinizi açıklayınız?” sorusu yöneltilmiştir. Katılımcıların yanıtları ikinci sınıflarda 11, 
üçüncü sinıflarda 14 ve dördüncü 14 olmak üzere toplam 20 kategori altında toplandığ1 belirlenmiştir. Tablo 9'de söz konusu kategorilere yer verilmiştir.

Tablo 9: Katılımcıların Akı1 Yürütme Türleri Hakkındaki Görüşleri

\begin{tabular}{|c|c|c|c|c|}
\hline Kategoriler & İkinci sınıf & Üçüncü sınıf & Dördüncü sınıf & Toplam \\
\hline Yanit yok & $\% 54$ & $\% 24$ & $\% 56$ & $\% 45$ \\
\hline Oyunla öğretim & $\% 13$ & $\% 3$ & $\% 9$ & $\% 8$ \\
\hline Tümevarım & $\% 3$ & $\% 8$ & $\% 5$ & $\% 6$ \\
\hline Tümdengelim & $\% 3$ & $\% 8$ & $\% 5$ & $\% 6$ \\
\hline Sentez & $\% 3$ & $\% 10$ & $\% 2$ & $\% 5$ \\
\hline Zihinsel süreç becerisi & - & $\% 3$ & $\% 5$ & $\% 3$ \\
\hline Somutlaştırma & $\% 3$ & $\% 3$ & $\% 4$ & $\% 3$ \\
\hline Analitik & $\% 3$ & $\% 5$ & $\% 2$ & $\% 3$ \\
\hline Analiz & - & $\% 10$ & - & $\% 3$ \\
\hline Soru-cevap & - & $\% 10$ & - & $\% 3$ \\
\hline Analoji & - & $\% 3$ & $\% 2$ & $\% 2$ \\
\hline Etkinlik & - & $\% 5$ & $\% 2$ & $\% 2$ \\
\hline Günlük yaşam & $\% 3$ & $\% 5$ & - & $\% 2$ \\
\hline Matematik & $\% 6$ & - & - & $\% 2$ \\
\hline Beyin furtınası & $\% 6$ & - & $\% 2$ & $\% 2$ \\
\hline Üretme & - & - & $\% 2$ & $\% 1$ \\
\hline Eleştirel düşünme & - & - & $\% 2$ & $\% 1$ \\
\hline Tahmin & - & - & $\% 2$ & $\% 1$ \\
\hline Soyut kavramları tanıma & $\% 3$ & - & - & $\% 1$ \\
\hline Uygulama & - & $\% 3$ & - & $\% 1$ \\
\hline TOPLAM & $\% 100$ & $\% 100$ & $\% 100$ & $\% 100$ \\
\hline
\end{tabular}

Tablo 9 incelendiğinde, katılımcıların büyük çoğunluğunun matematikte (ortaokul öğretim faaliyetlerinde) gerekli olan akıl yürütme türleri hakkında yanıt vermedikleri görülmüştür. Diğer yandan katılımcıların verdiği diğer cevaplar incelendiğinde oyunla öğretim, tümevarım ve tümdengelim cevapları takip etmektedir. Sınıflar bazında değerlendirildiğinde ise her sınıf türünde de yanıt vermeme oranı oldukça yüksektir. Üçüncü sınıflar, diğer sınıflara nazaran daha çok cevap veriş olduğu görülmektedir. Üçüncü sınıfların verdiği görüşler incelendiğinde analiz, sentez ve sorucevap kategorileri ön plana çıkmaktadır. Aşağıda sırasıyla en çok tekrarlanan "Yanıt Yok" kategorisi dışında ilk üç kategori olan "Oyunla öğretim", "tümevarım" ve "tümdengelim" kategorilerine ait örnek ifadelere yer verilmiştir.
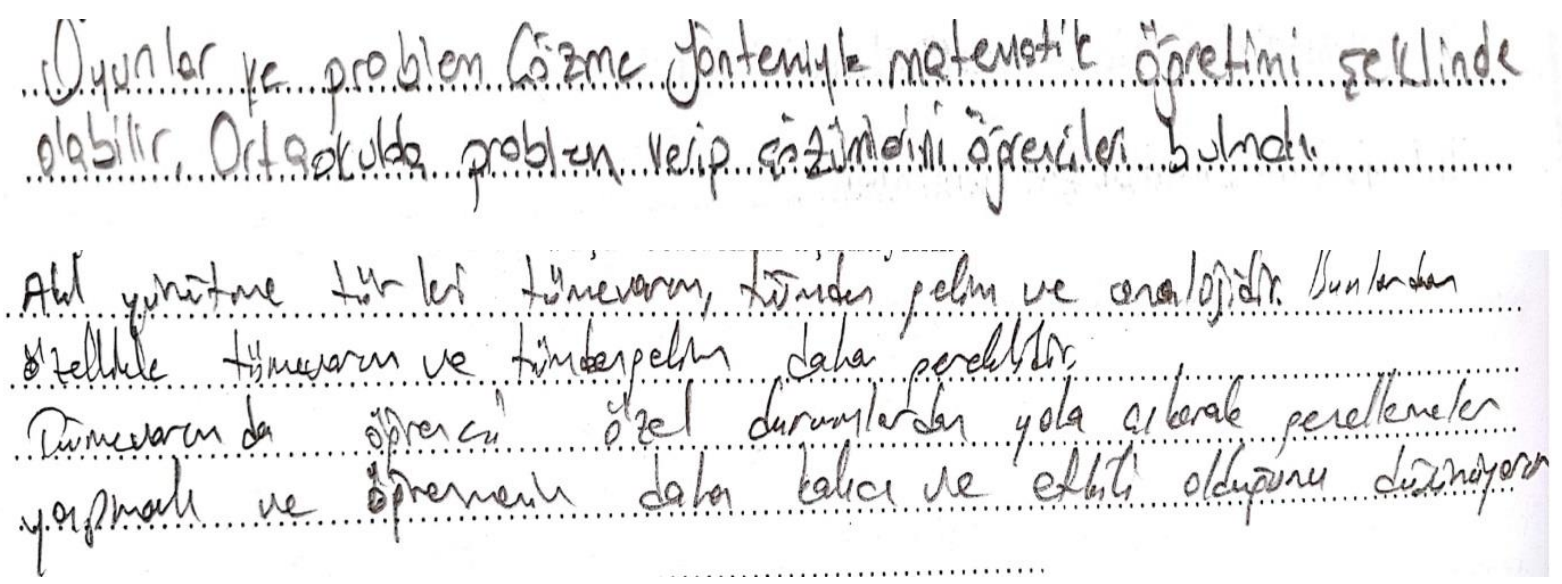


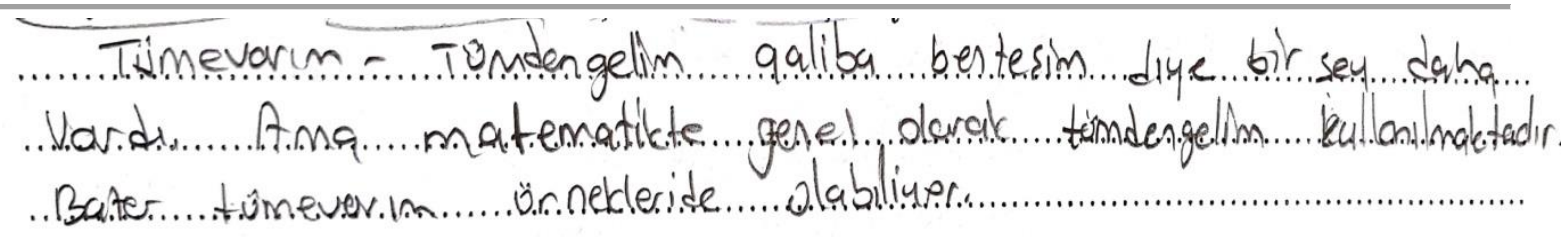

\section{Tartışma, Sonuç ve Öneriler}

$\mathrm{Bu}$ araştırmada ilköğretim matematik öğretmen adaylarının matematiksel akıl yürütme ve problem çözme becerileri konusundaki görüşleri derinlemesine incelenmiştir. Görüşme formu yoluyla toplanan nitel veriler içerik analizi yöntemi ile çözümlenmiştir. Çözümleme sürecinde öğretmen adaylarının görüşme formundaki her bir soruya verdikleri yanıtlar doğrultusunda kategoriler ve frekans dağılımları sınıf düzeylerine göre değerlendirilmiştir. Elde edilen veriler yorumlanarak araştırma sonuçları oluşturulmuştur.

Öğretmen adaylarının "Sizce "Problem" nedir? Nasıl tanımlarsınız?" sorusuna verdikleri cevaplardan elde edilen bulgular incelendiğinde, onlar için problem bir anlamda rahatsızlık veren bir olgu olarak değerlendirilebilir. Yine katılımcıların problemin tanımına yönelik görüşleri, güçlük, zorluk kategorisi olarak yukarıda belirtilen anlamlara yakındır. Baki (2018), problem çözme ile matematiksel akıl yürütme arasında çok yakın bir bağ olduğunu belirtmektedir. Bu açıdan ele alındığında problem çözme ile ilişkili akıl yürütme arasındaki bağlantı durumu "günlük hayat durumlarının matematiksel ifadesi" ve "düşündürmeye yarayan etkinlik" kategorilerinde görüldüğ̈̈ gibi çok nettir. Ancak bu durumun frekans dağ 11 m tablosunda yeterli bir düzeyde temsil edilmediği görülmektedir. Öğretmen adayları problemi, çözüm bekleyen eylem, durum, sorun, güçlük, zorluk ve yanıtı bulunması gereken soru kategorileri ele alındığında yüksek bir frekansla öğretmen adaylarının problemi literatüre uygun tanımladığı görülebilir. Çalışmadan elde edilen sonuç, John Dewey'in problemi insan aklını karıştıran, zorlaştıran ve inancı gizleyen her şey olarak yapmış olduğu tanımla paralellik göstermektedir (Baykul \& Aşkar 1987). Van De Walle (1994) problemi tipik olarak çözülmesi gereken bir araştırma veya tartışma gerektiren zor veya belirsiz bir soru olarak tanımlar. $\mathrm{Bu}$ açıdan da öğretmen adayları benzer açıklamalar yapmışlardır. Bu durum öğretmen adaylarının almış oldukları eğitim doğrultusunda bir tanımlama yapmaya çalıştıklarını göstermektedir.

"Matematikte problem çözme sizin için ne anlam ifade ediyor?" sorusundan elde edilen görüşler birinci soruya verilen cevaplardan elde edilen ve ana kategoride ifade edilen "sorun" ile tutarlılık göstermektedir. İlk dört kategori göz önüne alındığında öğretmen adaylarının matematiksel problem çözmeden çoğunlukla anladıkları olgunun "çözüm” olduğu görülebilir. Taşçı'nın (2005) problem çözmenin en genel anlamı bireylerin sorunlarına yönelik hedeflere ulaşmasıdır şeklindeki görüşüyle paralellik göstermektedir. Seferoğlu ve Akbıyık (2006) problem çözmenin tanımlanmış bir zorluğun üstesinden gelme, zorlukla ilgili toplanması gereken veriyi belirleme, çözümler üretme, üretilen çözümleri sınama becerilerini içerdiğini belirtmiştir. Öğretmen adaylarının çözüm odaklı düşünmeleri matematik eğitimi alan her yaş gurubundaki bireyler için yabancı bir kavram değildir. Ancak onların eğitim süreci incelendiğinde bu istendik bir durum değildir. Öğretmen adaylarının problem çözmeyi mutluluk olarak ifade etmesi tutum açısından önemlidir. Ancak bu sezgisel bir durumdur. Tam bilince çıkarılmamış ancak sonuçları itibari ile birtakım hislere sahip olunması bu durumun yeterli düzeyde kavranmadığına işaret eden bir durum gibi görünmektedir. Bunun yanında Kilpatric ve diğerlerinin (2001) belirlemesine kıyasla öğretmen adaylarının problem çözmeyi "mantıksal düşünmedir" şeklinde tekil ve basit olarak ifade etmeleri, akıl yürütmenin yeterli düzeyde literatüre uygun olarak anlamlandırılmadığı şeklinde değerlendirilebilir. Bu durum öğretmen adaylarının akıl yürütme konusunda bilgilerinin olmadığ 1 veya yetersiz olduğu biçiminde yorumlanabilir.

Öğretmen adaylarının "Bir matematikçi gözüyle matematiksel akıl yürütme sizin için ne anlam ifade ediyor?" sorusuna verdikleri cevaplardan şu sonuçlara ulaşılabilir. Akıl yürütmenin 
birinci koşulu anlaşılır ifadelerle anlaşılır açıklamalar yapmaktır. Bu açıdan öğretmen adaylarının Brodie'nin (2010) belirtmiş olduğu akıl yürütme bileşenleri ile ilgili yeterli bilgilerinin olmadığı söylenebilir. Problem çözme bağlamından bakıldığında problemde ele alınan ifadelerin/durumların (sorunu teşkil eden kısımlar veya bir bütün olarak problemin kendisi) matematiksel hale getirilmesinin bir takım alt basamaklarının olması gerekir. Burada bahsedilen basamaklar, anlaşılır ifadeler ileri sürme ve savunma, doğru sembolleștirme, genelleme yapma gibi alt basamaklardır. Ancak görüldüğü gibi problem çözme düzleminden bakan bir öğretmen adayı bu olguya Matematiğ $i$ kullanarak cevaplamak, çözüm yolları üretmek, var olan önermelerden yeni önermeler ve problemi çözme stratejisi kategorilerinden görüldüğü üzere bir çözüm bulma stratejisi olarak yaklaşmaktadır. Burada ayrıca dikkat çeken ve öğretmen adaylarından beklenen Mantıksal düşünme, soyut kavramları daha iyi ifade edebilme, problemi anlaşıllı hale getirmek, durumlara, olaylara analitik düsünmeyle yaklaşmak, matematiksel düşünceyle tutarlı olarak yorum yapma ve ayrıntılarla irdelemek kategorilerinde gerçekten matematiksel akıl yürütmeyi dolaylı olarak ve bazıları doğrudan tarif eden kategorilerin var olduğudur. Bu öğretmen adaylarının şimdiye kadar olan eğitim yaşantılarında matematiksel akıl yürütmeye yönelik olarak olumlu bir bilgi birikimi geliştirdiklerini ve bu bilgilerin farkında olduklarını gösteren bir durum olarak düşünülebilir. Ancak belirtmek gerekir ki bu kategorilerin frekansları bir çoğunluk göstermemektedir. Bu yönüyle eğitim yaşantılarının sonucu olarak bireysel çıkarıma dayalı olduğu söylenebilir. Araştırmanın bu boyutundan elde edilen sonuçlar Loong, Vale, Bragg ve Herbert'in (2013) bazı öğretmenlerin akı1 yürütmenin anlamını söyleyebildikleri halde bazılarının problem çözme ile akıl yürütme becerisi kavramlarını karıştırma gibi belirsiz ifadeler kullanmaları bulgularıyla benzerlik göstermektedir.

Öğretmen adaylarının "Matematiksel Akal Yürütme hakkında lisans öğrenimi süresince verilen eğitimler konusundaki düşünceleriniz nelerdir? Açılayınız?" sorusuna verdikleri cevaplardan yeterli düzeyde akıl yürütme eğitimi almadıkları görülmektedir. Bunu mutlak anlamda değerlendirebileceğimiz gibi onların eğitim süreçlerinde kendilerine informal olarak isimlendirilmeden öğretilmiş olan akıl yürütme becerilerinin farkında olmadıkları şeklinde de ele alabiliriz. Nitekim bir önceki soruya verdikleri cevaplar ve yapmış oldukları bazı açıklamalar buna işaret etmektedir. Erdem (2015) çalışmasında farklı öğretim yöntemlerinin kullanılmasıyla öğrencilerin matematiksel akıl yürütme becerilerinin arttığı sonucuna ulaşmıştır. $\mathrm{Bu}$ açıdan bakıldığında öğretmen adaylarının doğrudan muhakeme bileşenlerini adlandıran ve uygulamaları bu doğrultuda gerçekleştiren derslere ihtiyaç duydukları söylenebilir.

Öğretmen adaylarının "Sizce "Matematiksel Akll Yürütme" ile "Problem Çözme” arasında nasıl bir ilişki vardır?" sorusuna verdikleri yanıtlar; önceki sorulara verdikleri akıl yürütmeye ilişkin açıklamalarla tutarlılık görünmektedir. Ayrlmaz bir bütündür ve problem çözme işlemi gerçekleşirken matematiksel akal yürütme kullanılır kategorileri göz önüne alındığında problem çözme süreci problem tanımı içinde düşünülecek olunursa öğretmen adaylarına göre akıl yürütme olmaksızın problem çözmek çok mümkün görünmemektedir. "Problem çözme sürecinde akıl yürütme kullanılırsa daha aktif ve daha hızlı olunur", "akıl yürütme araçtır", "problem çözme sürecinde kullanilan yöntemdir", "problem çözmede somut bir işlem ele alınır ancak akl yürütmede soyut düşünme ön plandadır", "akll yürütme gidiş yolu, problem çözme sonuç ve problem çözmede soyut düşünme ön plandadır ancak akl yürütmede somut bir işlem ele alınır" kategorileri incelendiğinde öğretmen adaylarının akıl yürütme olgusuna farklı bir bakış açısı ile yani pür düşünme olgusu ile yaklaştığı görülmektedir. Çünkü bu kategoriler incelendiğinde akıl yürütme sanki bir yöntem gibi algılanmaktadır. Bu yönüyle öğretmen adaylarının akıl yürütmeden ifade ettikleri şey burada literatüre uygun değildir. Kategoriler dikkate alındığında öğretmen adaylarının ifade ettiği "herhangi bir eğitim almadık" durumu burada önem arz etmektedir. Bu bağlamda öğretmen adaylarının akıl yürütmenin bir takım alt bileşenlerini kullanıyor olsa dahi kullanmış oldukları bu akıl yürütme tipinin farkında olmadıkları söylenebilir. Buna ek olarak öğretmen adaylarının belirtmiş olduğu görüşler Özdemir, Duran ve Kaplan (2016) yaptıkları çalışmada matematik literatüründe 
problem çözme tanımında belirtilen problem çözme eyleminin birtakım işlemler eşliğinde akıl yürütme süreçleri çalıştırılarak ve gerekli bilgiler kullanılarak sorunun ortadan kaldırılması ifadesine paralel olarak görüş belirttikleri söylenebilir.

Akıl yürütme günlük yaşamda en çok karşımıza bazı akıl yürütmeyi gerektiren oyunlar düzleminde karşımıza çıkmaktadır. Bu nedenle katılımcılara "Akıl Yürütme Oyunları hakkında bilginiz var mı? Hangi oyunları örnek verebilirsiniz?” sorusu yöneltilmiștir. Kategoriler dikkate alındığında öğretmen adaylarının akıl yürütme becerilerini yakın ilgilendiren bazı oyunları ifade ettikleri görülmektedir. Buradaki oyunlar göz önün alındığında "satrancın" önemli yer tutması yukarıdaki sorulara verdikleri cevaplarla tutarlı görünmektedir. Satranç oyunundaki bir hamlenin amacını açıklama varken mutlak ispattan bahsedemeyiz. Dolayısıyla burada bahsedilen akıl yürütmenin diğer bileşenleri hakkında fazla bir şey söylemek mümkün görünmemektedir. Aynı olgu sudoku için geçerli değildir. Çünkü sudoku'da çözümün her zaman bir sağlaması vardır. Kategoriler üzerinden ele alındığında öğretmen adaylarının akıl yürütme konusunda en fazla amacın açıklanması dışındaki diğer alt başlıklara dikkat etmedikleri söylenebilir. Bu önemli ölçüde düşünmenin tanımı ile yakın alakalıdır ki genel olarak bu tür düşünmeler amaçlı olmakla birlikte matematiksel bir özellik göstermeyebilir. Bunun yanında öğretmen adaylarının akıl yürütmeyi gerektiren oyunlara karşı herhangi bir ilgilerinin olmadığı ayrıca söylenebilir.

Matematik müfredatları incelendiğinde akıl yürütme olgusunun olmadığı bir müfredatın olması düşünülemez. Yapılandırmacı yaklaşımın hâkim olduğu günümüz matematik eğitimi müfredatları bilginin ancak düşünülerek inşa edilebildiğine yönelik önemli kanıtlara sahiptir. Böyle bir düzlemde öğretmen adaylarına bu yönlü görüslerinin neler olduğuna yönelik "Sizce "Matematiksel akıl yürütme becerisi" MEB matematik ögretim müfredatında yer almalı mıdır? Neden açılayınız?" sorusu sorulmuştur. Öğretmen adaylarının görüşleri, yeterli düzeyde matematiksel akıl yürütmeyi anladığına yönelik bir gösterge yoktur şeklindedir. Özellikle belli bir kategorinin ağırlıklı olarak baskınlığının olmayışı öğretmen adaylarının bu konuda nasıl düşündüklerine yönelik tam bir ipucu vermemektedir. Bununla birlikte öğretmen adaylarının genel olarak algıladıkları veya informal olarak öğrendikleri kadarıyla matematiksel akıl yürütmenin çok önemli bir beceri olduğunun hissindedirler. Tam anlamıyla bir bilinçlilik durumu bilgi durumuyla yakın ilişkili olduğu için burada katılımcıların bilgilerinin yeterli olmadığı göz önüne alınırsa, sezgisel olarak akıl yürütmenin geçmiş yaşantılarının etkisi ile de olsa bir farkındalık söz konusu edilebilir. Öğretmen adaylarının verdikleri cevaplar bu yönüyle ele alınması durumunda akıl yürütmeye ilişkin görüşleri beklenildiği gibi olumlu olmalıdır. Ancak bu olumlu durum tutuma daha yakın olduğunu düşündürmektedir. Yukarıda ifade edilen akıl yürütmeye ilişkin öğretmen adaylarının, akıl yürütmenin müfredatta olması gerektiğine yönelik olumlu cevapları ağırlıktadır benzer bir amaçla ancak farklı bir ilişki boyutu ortaya çıkarmak amacıyla sekizinci soru yöneltilmiştir. Gerçekte öğretmen adaylarının cevapları beklenen bir niteliktedir ve onlara göre; matematiksel akıl yürütme ile matematik başarısı arasında pozitif yönde güçlü bir bağ vardır. Yani matematiksel akıl yürütme becerisi matematik başarısını artırmaktadır. Ulaşılan bu bulgu literatürdeki benzer çalışmaların sonuçlarıyla paralellik göstermektedir (Lutfiyya, 1998; Bağdat \& Saban, 2014). Bu duruma ilişkin olarak öğretmen adaylarının doğrudan akıl yürütme bileşenlerini ilgilendiren problem çözme süreçlerine dahil olması ve bu süreçte ayrıntılı akıl yürütme bileşenleri üzerinde çalışması gerektiği kanısı uyandırmaktadır.

Yukarıda ifade edilen akıl yürütmeye ilişkin öğretmen adayları akı1 yürütmenin müfredatta olması gerektiğine yönelik olumlu cevapları ağırlıktadır benzer bir amaçla ancak farklı bir ilişki boyutu ortaya çıkarmak amacıyla "Matematiksel akıl yürütme ve matematik başarısı arasında nasıl bir ilişki olduğunu düşünüyorsunuz? Açıklayınız." görüş sorusu yöneltilmiş̧ir. Gerçekte öğretmen adaylarının cevapları beklenen bir niteliktedir. Öğretmen adaylarından alınan görüşlere göre matematiksel akıl yürütme ile matematik başarısı arasında pozitif yönde güçlü bir ilişki vardır. Yani 
matematiksel akıl yürütme becerisi matematik başarısını artırmaktadır. Ulaşılan bu sonuç ile Lutfiyya (1998) ve Bağdat ve Saban (2014)'nın çalışmalarında ulaşılan sonuçlar benzerdir.

Yukarıdaki açıklamalar dikkate alındığında öğretmen adaylarının son soruya verdikleri cevaplardan, oyun etkinliklerinin önemli bir yer tuttuğu söylenebilir. Ayrıca "Araştırma ve düşünmeye sevk edecek etkinlikler”, "çeşitli problemler çözülmeli”, "Konular günlük hayatla ilişkilendirilerek anlatılmalı", "Materyal”, "Öğrencilerin hazır bulunuşluk düzeylerine uygun problemler sunulmall", "akıl yürütme ders olarak verilmeli" kategorileri ak1l yürütmede önemlidir. Örneğin konuların günlük hayatla ilişkilendirilmesi matematiğin soyut ve ezberlenmesi gereken bir olgu olmasının ötesinde akıl yürütmenin günlük yaşamda işe yararlılığına yönelik olumlu bir algı yaratacaktır. Böylece insan doğasının faydacı yaklaşımı, matematiğe yönelik tutum ve motivasyonu olumlu etkileyecektir. Bu durumun matematiğe olan ilgiyi ve başarıyı artıracağına ilişkin görüşler hakimdir. Bu durum aynı zamanda ögretmen adaylarının eksiklik his ettikleri konulara da dolaylı olarak 1şık tuttuğu düşünülmektedir.

Öğretmen adaylarının "Sizce matematikte (ortaokul ögretim faaliyetlerinde) gerekli olan akll yürütme türleri nelerdir? Bu akıl yürütme türleri hakkındaki düşüncelerinizi açılklayınız?" sorusuna verdikleri cevaplar değerlendirildiğinde, Yanıt yok kategorisi onların akıl yürütme ile ne ifade edildiği konusunda yeterli bilgilerinin olmadığına yönelik önemli ipuçları vermektedir. Öğretmen adaylarının ifade ettikleri tümevarım ve tümdengelim gerçekte matematiksel düşünmenin önemli bileşenlerinden olmasına rağmen buradaki ifadelerinde daha çok "genelleme" ve "sonuç çıkarma" biçiminde anlamlandırılmaktadır. Bu durum ise öğretmen adaylarının kavramları doğru bir temelde anlamlandırmadıklarına ilişkin bir göstergedir. Diğer kategoriler ele alındığında bu durum daha nettir. Kilpatrick ve diğerleri (2001) ve Brodie'nin (2010) akıl yürütme için belirtmiş oldukları sentez, somutlaştırma, beyin firtınası, etkinlik, günlük yaşam, matematik gibi ifadeler dikkate alındığında bu çalışma için öğretmen adaylarının akıl yürütme kavramını iyi tanımadığı veya tanımlayamadığı söylenebilir. Bu durum öğretmen adaylarının lisans süresince almış oldukları derslerde bu konunun yeterince ele alınmadığı ve dolayısıyla öğretmen adayları bu konuda yeterince derinleşemedikleri şeklinde yorumlanabilir

Araştırma sonucunda; öğretmen adaylarının yeterli akıl yürütme bilgi birikimine sahip olmadıkları, böyle bir eğitime ihtiyaç duyduklanı, informal olarak bazı bileşenleri hakkında sezgilere sahip oldukları ve akıl yürütmeye karşı olumlu tutum sergiledikleri söylenebilir. Aldıkları eğitimlere rağmen problem çözme konusundaki inanışlarında geçmiş tutum ve yaklaşımlarının sürdüğü ve bu doğrultuda sonuç odaklı düşünme süreçlerini korudukları söylenebilir. $\mathrm{Bu}$ durum öğretmen adaylarının aldıkları eğitimde doğrudan akıl yürütme eğitimi almaları ve bunları formal olarak tanımlayıp alt bileşenleri üzerinde inceleme yapmaya ihtiyaç duydukları söylenebilir. Böylece bir takım akıl yürütme bileşenleri hakkında doğrudan düşünme sağlayarak bu süreçleri kendi düşünme süreçlerine dâhil edebilme şansı yakalamaları olası olacaktır. Ayrıca bu çalışmanın gösterdiği kadarıyla öğrenen grupları açısından akıl yürütme olgusu üzerinde hala daha derin inceleme yapılmasına ihtiyaç olduğudur. Var olan bileşenler üzerinden bile değerlendirme yapıldığında bu bileşenlerin çeşitli alt bileşenlerinin ortaya çıkma durumu söz konusu olabileceğinden bu yönlü çalışmalara ihtiyaç olduğu yönündedir. Öğretmen adaylarının problemin ne olduğuna dair yetersiz yorumlar yaptıkları açıktır. Bu yönüyle problem çözme ve akıl yürütme arasındaki ilişkilerin doğru bir perspektifte inşa edilmesi öğretmen adaylarının farklı durumlarda nasıl akıl yürütmeleri gerektiği konusunda olumlu yönde etki gösterecektir. Bu amacın gerçekleştirilmesi için araştırmacıların önerisi gerek müfredat bazında gerekse de ders içerikleri bazında yapılacak birtakım geliştirmeler öğretmen adaylarının ve dolayısıyla yetiştirilmekte olan öğrenci kitlemizin matematik anlayışına ve başarısına katkı göstereceği yönündedir. 


\section{Kaynakça}

Anderson, E. H., \& Spencer, M. H. (2002). Cognitive representations of AIDS: A phenomenological study. Qualitative Health Research, 12(10), 1338-1352.

Baki, A. (2018). Matematiği ögretme bilgisi. Pegem Akademi

Ball, D. L., \& Bass, H. (2003). Making mathematics reasonable in school. In J. Kilpatrick, W. G. Martin, \& D. Schifter (Eds.), A research companion to principles and standards for school mathematics (pp. 27-44). Reston, VA: National Council of Teachers of Mathematics.

Baykul, Y., \& Aşkar P. (1987). Problem ve problem çözme, matematik öğretimi. Açıögretim Fakültesi Yayınları, No: 94.

Bağdat, O., \& Saban, P. (2014). İlköğretim 8. sınıföğrencilerinin cebirsel düşünme becerilerinin solo taksonomisi ile incelenmesi. International Journal of Social Science, 26, (2), 473-496. http://dx.doi.org/10.9761/JASSS2364

Berkant, H. G., \& Kandırmaz, M. (2018). Ortaokul matematik öğretmenlerinin öğrencilerin matematik dersi becerilerini geliştirme yeterliklerinin incelenmesi. International Journal of Eurasian Education and Culture, 3(5), 132-154.

Brodie, K. (2010). Teaching mathematical reasoning in secondary school. Springer.

Büyüköztürk, Ş., Kılı̨̧ Çakmak, E., Akgün, Ö. E., Karadeniz, Ş., \& Demirel, F. (2016). Bilimsel araştırma yöntemleri. Pegem Akademi.

Campbell, A. E., Adams, V. M., \& Davis, G. E. (2007). Cognitive demands and second language learners: A framework for analyzing mathematical instructional contexts. Mathematical Thinking and Learning, 9(1), 3-30.

Creswell, J. W. (2013). Qualitative inquiry \& Research design: Choosing among five approaches (3rd ed.). SAGE.

Çiltaş, A. (2011). Dizi ve seriler konusunun matematiksel modelleme yoluyla öğretiminin ilköğretim matematik öğretmeni adaylarının ögrenme ve modelleme becerileri üzerine etkisi (Yayımlanmamış doktora tezi). Atatürk Üniversitesi.

Eraut, M. (2004). Informal learning in the workplace. Studies in continuing education, 26(2), 247273. http://dx.doi.org/10.1080/158037042000225245

Erdem, E. (2015). Matematiksel muhakemeyi geliştirmeye yönelik tasarlanan öğrenme ortamının etkileri (Yayınlanmamış doktora tezi). Atatürk Üniversitesi.

Fathima, M. S., \& Rao, D. B. (2008). Reasoning ability of adolescent students. Discovery Publishing House.

García, T., Boom, J., Kroesbergen, E. H., Núñez, J. C., \& Rodríguez, C. (2019). Planning, execution, and revision in mathematics problem solving: Does the order of the phases matter? Studies in Educational Evaluation, 61, 83-93. http://dx.doi.org/10.1016/j.stueduc.2019.03.001

Hasırcı, S. (2017). Türkçe öğretmeni adaylarının çocuk edebiyatına ilişkin algılarının metaforlar aracilığıla analizi. The Journal of International Social Research, 10(51), 717-728. http://dx.doi.org/10.17719/jisr.2017.1808

Jäder, J., Sidenvall, J., \& Sumpter, L. (2017). Students' mathematical reasoning and beliefs in nonroutine task solving. International Journal of Science and Mathematics Education, 15, 759776. http://dx.doi.org/10.1007/s10763-016-9712-3 
Kaur, B. (1997). Difficulties with problem solving in Mathematics. The Mathematics Educator, 2(1), 93-112

Kocabıyık, O. O. (2016). Olgubilim ve gömülü kuram: Bazı özellikler açısından karşılaştırma. Trakya Üniversitesi Ĕ̈itim Fakültesi Dergisi, 6(1), 55-66

Kilpatric, J., Swafford, J., \& Findell, B. (Eds.) (2001). Adding it up: Helping children learn mathematics. Washington, DC: National Academy Press.

Loong, E., Vale, C., Bragg, L., \& Herbert, S. (2013). Primary school teachers' perceptions of mathematical reasoning. In V. Steinle, L. Ball \& C. Bardini (Eds.), Mathematics education: Yesterday, today and tomorrow. Proceedings of the Thirty-Sixth Annual Conference of the Mathematics Education Research Group of Australasia (pp. 466-472). MERGA

Lutfiyya, A. L. (1998). Mathematical thinking of high school students in Nebreska. Int.J. Math.Educ.Sci.Technol. 29(1), 55-64.

MEB. (2013). Ortaokul matematik dersi (5, 6, 7 ve 8. Sinıflar) öğretim programı. Millî Eğitim Bakanlığı, Talim ve Terbiye Kurulu Başkanlığı.

Miles, M. B., \& Huberman, A. M. (1994). An expanded sourcebook: qualitative data analysis (2nd Editon). SAGE.

Najdowski, A. C. (2017). Flexible and focused teaching executive function skills to individuals with autism and attention disorders. Academic Press. http://dx.doi.org/10.1016/B978-0-12809833-2.00006-6.

NCTM. (2009). Focus in high school mathematics: Reasoning and sense making. Reston, VA: National Council for Teachers of Mathematics.

Osman, S., Yang, C.N.A.C., Abu, M.S., Ismail, N., Jambari, H., \& Kumar, J.A. (2018). Enhancing students' mathematical problem-solving skills through bar model visualisation technique. International Electronic Journal of Mathematics Education, 13(3), 273-279. http://dx.doi.org/10.12973/iejme/3919

Öz, T., \& Işık, A. (2017). İlköğretim matematik öğretmeni adaylarının matematiksel akıl yürütme becerisi üzerine görüşleri. Erzincan Üniversitesi Eğitim Fakültesi Dergisi, 19(2), 228-249. http://dx.doi.org/10.17556/erziefd.292622

Özdemir, F., Duran, M., \& Kaplan, A. (2016). Ortaokul öğrencilerinin görsel matematik okuryazarlı̆̆ özyeterlik algıları ile problem çözme beceri algılarının incelenmesi. Kuramsal Ë̆itimbilim Dergisi, 9(4), 532-554. http://dx.doi.org/10.5578/keg.27822

Özdemir, F., \& Kaplan, A. (2017). Öğretmen adaylarının bakış açısından Türk eğitim sisteminin sorunları ve bu sorunlara yönelik çözüm önerileri. International Periodical for the Languages, Literature and History of Turkish or Turkic, 12(28), 577-592. http://dx.doi.org/10.7827/TurkishStudies.12426

Patton, M. (2002). Qualitative research and evaluation methods. SAGE.

Posamentier, A. S., \& Krulik, S. (2016). Matematikte problem çözme 3-6 sinıflar (L. Akgün, T. Kar, \& M. F. Öçal, çev.). Pegem Akademi.

Rohana. (2015). The enhancement of student's teacher mathematical reasoning ability through reflective learning. Journal of Education and Practice, 6(20), 108-114

Seferoğlu, S. S., \& Akbıyık, C. (2006). Eleştirel düşünme ve öğretimi. Hacettepe Üniversitesi Eğitim Fakültesi Dergisi, 30(30), 193-200. 
Sevim, O. (2015). Influence of the subject jigsaw technique on elementary school seventh grade students' academic achievement and on their problem solving skills. Education and Science, 40(177), 385-400. http://dx.doi.org/10.15290/EB.2015.3748

Sprigler, D. M., \& Alsup, J. K. (2003). An analysis of gender and the mathematical reasoning ability sub-skill of analysis-synthesis. Education, 123(4), 763-769.

Tambychik, T., \& Meerah, T.S.M. (2010). Students' difficulties in mathematics problem-solving: What do they say? Procedia Social and Behavioral Sciences, 8, 142-151. http://dx.doi.org/10.1016/j.sbspro.2010.12.020

Taşç1, S. (2005). Hemşirelikte problem çözme süreci. Journal of Health Sciences, 14, 73-78.

Thom, J. (2011). Nurturing mathematical reasoning. Teaching and Learning Mathematics, 18(4), 234-243.

TIMSS. (2003). IEA's TIMSS 2003 international report on achievement in the mathematics cognitive domains. TIMSS \& PIRLS International Study Center, Lynch School of Education Boston College. https://timssandpirls.bc.edu/PDF/t03_download/T03MCOGDRPT.pdf

Topçuoğlu Ünal, F., \& Tekin, M. T. (2013). Eleştirel yazmaya ilişkin türkçe öğretmeni adaylarının $\begin{array}{lllll}\text { metaforik algiları. } & \text { Turkish } & \text { Studies, } & 8(13), & 1595-\end{array}$ http://dx.doi.org/10.7827/TurkishStudies.5989

Umay, A., \& Kaf, Y. (2005). Matematikte kusurlu akıl yürütme üzerine bir çalışma. Hacettepe Üniversitesi Eğitim Fakültesi Dergisi, 28, 88-195.

Vagle, M.D. (2014). Crafting Phenomenological Research. Walnut Creek, CA: Left Coast Press.

Van De Walle, J. A. (1994). Elementary school Mathematics. Longman.

Yeşildere, S., \& Türnüklü, E. B. (2007). Öğrencilerin matematiksel düşünme ve akı1 yürütme süreçlerinin incelenmesi. Ankara Üniversitesi Ĕ̈itim Bilimleri Fakültesi Dergisi, 40(1), 181 213.

Yıldırım, A., \& Şimşek, H. (2013). Sosyal bilimlerde nitel araştırma yöntemleri. Seçkin Yayıncılık.

Yurt, E., \& Sünbül, A. M. (2014). Sekizinci sınıf öğrencilerinin matematik başarılarını açıklayan bir yapısal eşitlik modeli. Kuram ve Uygulamada Ĕ̈itim Bilimleri, 14(4), 1629-1653 